Chicago-Kent College of Law

Scholarly Commons @ IIT Chicago-Kent College of Law

All Faculty Scholarship

Faculty Scholarship

June 2007

\title{
Of the World Trade Court's Burden
}

Sungjoon Cho

IIT Chicago-Kent College of Law, scho1@kentlaw.iit.edu

Follow this and additional works at: https://scholarship.kentlaw.iit.edu/fac_schol

Part of the International Law Commons, and the International Trade Law Commons

\section{Recommended Citation}

Sungjoon Cho, Of the World Trade Court's Burden, (2007).

Available at: https://scholarship.kentlaw.iit.edu/fac_schol/177

This Article is brought to you for free and open access by the Faculty Scholarship at Scholarly Commons @ IIT Chicago-Kent College of Law. It has been accepted for inclusion in All Faculty Scholarship by an authorized administrator of Scholarly Commons @ IIT Chicago-Kent College of Law. For more information, please contact jwenger@kentlaw.iit.edu, ebarney@kentlaw.iit.edu. 


\title{
Of the World Trade Court's Burden
}

\section{Sungjoon Cho*}

\author{
"We are not final because we \\ are infallible; but we are \\ infallible only because we are \\ final."
}

\section{Table of Contents}

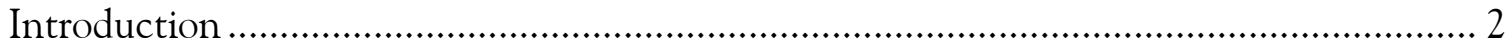

I. Parties' Burden: The Conventional Approach on the Burden of Proof in International

Trade Law

II. The World Trade Court's Burden: Reconstructing the Burden of Proof in International

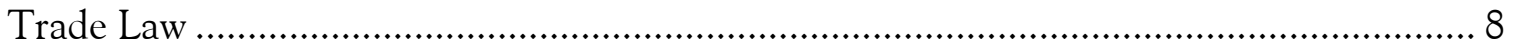

A. From Parties' Burden to the Court's Burden........................................................... 8

B. Three Hermeneutical Burdens of the Court........................................................... 13

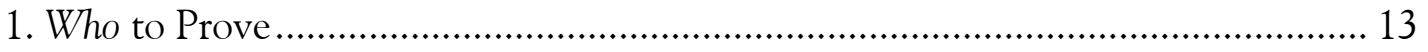

2. What to Prove

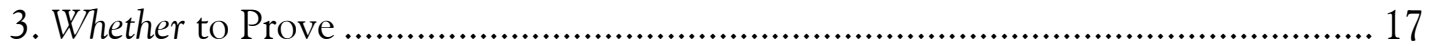

4. A Cumulative Nature of Three Burdens......................................................... 18

III. What Lies beneath the World Trade Court's Burden: The Judicialization of Science20

A. The Judicial Regulation of Science ...................................................................... 20

B. Scientific Uncertainty, Hercules and Phronesis ........................................................... 22

IV. Appraising the World Trade Court's Burden: A Critical Perspective ........................ 25

A. Diverging Oracles from Hercules: Incoherent Jurisprudence …………………........ 25

1. Incoherency within the SPS Agreement ........................................................... 26

2. Incoherency between GATT and the SPS Agreement......................................... 28

3. Inconsistency between Law and Facts ............................................................. 32

B. Finality over Legitimacy: Legitimacy Crisis ............................................................. 34

1. Judicialization as Finality..................................................................................... 34

2. Over-Regulative Finality: Science under Politics ...................................................... 35

3. Under-Regulative Finality: Regulatory Autonomy Lost ......................................... 38

4. Finality without Compliance Pull: Legitimacy at Risk .............................................. 39

V. Discharging the World Trade Court's Burden: A Procedural Turn .............................. 41

- Assistant Professor of Law, Chicago-Kent College of Law, Illinois Institute of Technology. I would like to extend my deepest gratitude to my mentor, Professor Joseph H.H. Weiler, for his extraordinary guidance and support without which this Article would have never been possible. All errors are mine.

${ }^{1}$ U.S. Supreme Court Justice Robert Jackson in Brown v. Allen, 344 U.S. 443, 540 (1953) (concurring opinion) (quoted in RICHARD H. GASKIN, BURDEN OF PROOF IN MODERN DISCOURSE 242 (1992)). 
A. A Copernican Turn: Legitimacy over Finality …………………………………...... 42

B. Discharging the Court's Burden: Reinterpreting WTO Provisions on Risk

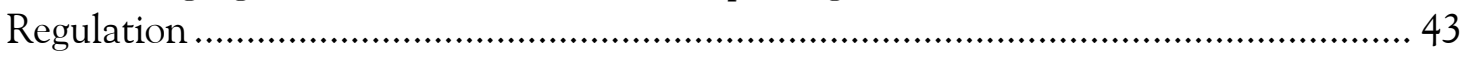

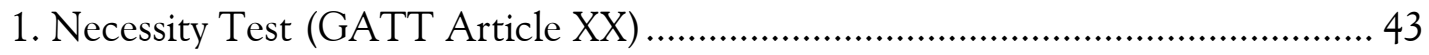

2. Harmonization (SPS Article 3) ........................................................................... 44

3. Risk Assessment (SPS Article 5.1) ........................................................................ 46

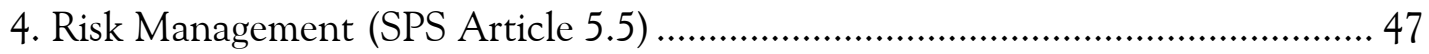

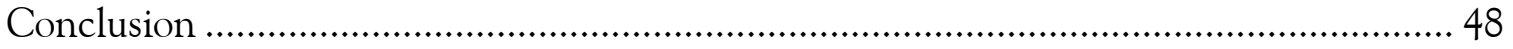




\section{Introduction}

Ever since the historic launch of the World Trade Organization (WTO), its dispute resolution tribunal, the World Trade Court (the Court), ${ }^{2}$ has commanded both attention and admiration from its users and commentators. This crown jewel of the WTO system has attracted over 350 cases in the past decade. ${ }^{3}$ The Court has addressed three times more cases than the International Court of Justice (ICJ) has done during the latter's half-century of existence. ${ }^{4}$

Ironically, however, the Court's magnetism has been a mixed blessing. In addition to conventional trade issues, such as tariffs and subsidies, it has also attracted high profile cases characterized by scientific controversies and socio-cultural sensitivities. The Court's decisions on these sensitive cases have often caused resentment from some groups, besides losing parties. For example, the Court's Hormones decision in 1998, which struck down the European Union (EU)'s ban on the importation of hormone-treated beef from the United States on the ground that the ban was adopted with no scientific evidence, ${ }^{5}$ irked many governments and consumer organizations which accused the Court of forcing them to accept low regulatory standards in the name of science. ${ }^{6}$ Four years later, the EU resurrected the same ban under a new scientific justification. ${ }^{7}$

Beneath this disapproval of the Court lies an image of a Dworkinian Hercules which capriciously renders its own answers on risks and science. ${ }^{8}$ In judging which party should win the case, this Hercules assesses parties' arguments and evidence on risks and regulatory responses through a technical rule labeled the "burden of proof" (BOP). In the traditional approach used under public international law, the BOP is mainly the parties' burden: any party which invokes a certain fact bears the burden of proving its veracity

\footnotetext{
${ }^{2}$ In this Article, I use "World Trade Court" or "Court" only in a metaphoric sense. Technically, the WTO tribunal, i.e., a panel or the Appellate Body, is not a court per se and its decision constitutes a "recommendation" to the WTO Dispute Settlement Body (DSB). WTO Dispute Settlement Understanding (DSU), art. 19. Nonetheless, it is still a "judicial" or at least "quasi-judicial" organ which performs an adjudicative function.

${ }^{3}$ World Trade Organization List of Disputed Cases, http://www.wto.org/english/tratop_e/dispu_e/dispu_status_e.htm (last visited Feb. 24, 2007).

${ }^{4}$ List of Cases Brought Before the International Court of Justice, http://www.icjcij.org/icjwww/idecisions.htm (last visited Feb. 24, 2007).

${ }^{5}$ Appellate Body Report, European Communities-Measures Concerning Meat and Meat Products (Hormones), ๆ197, WT/DS26/AB/R (Jan. 16, 1998).

${ }^{6}$ Debi Barker \& Jerry Mander, InVisible Government. The World Trade OrganizATIOn: GLOBAL GOVERNMENT FOR THE NEW MILLENNIUM? 26 (1999).

${ }^{7}$ See Raj Bhala \& David A. Gantz, WTO Case Review 2004, 22. ARIZ J. INT'L \& COMP. L. 99, 114 (2005).

${ }^{8}$ See generally RONALD DOWRKIN, LAW'S EMPIRE (1986).
} 
(actori incumbit probation ${ }^{9}$ ). This position was affirmed in an early WTO case, Shirts and Blouses. ${ }^{10}$ Therefore, for strategic reasons, parties have been preoccupied with the allocation of the BOP. A complaining party tends to argue that a defending (regulating) party's regulation can be invoked only as an "exception" to a contrary obligation so that the latter should prove necessary facts for the exception. On the other hand, the defending party tends to argue that it has a "right" to regulate in the first place so that the former should prove conflicting facts which may rebut this presumption.

However, how Hercules weaves its own (right) answers on risks and science, and who it will pick in the end as a winner is related only remotely to the BOP as defined as the parties' burden, i.e., the allocation of the BOP (who to prove). No matter how hard a party attempts to strategize this aspect of the BOP in the proceeding, it is the Court which determines such allocation via interpretation. Furthermore, even if who to prove is determined, the final outcome of the case hinges eventually on those elements which the Court requires parties to prove (what to prove) as well as whether the Court approves that a party has discharged its BOP and allows the burden to shift to the other party (whether to prove). Therefore, the BOP is in fact the Court's hermeneutical burden.

Then, what has been the rationale, or a driving force, behind the Court's interpretive stance on these BOP issues, such as who to prove, what to prove and whether to prove, in those disputes regarding risks and regulation? This Article argues that it has been a "judicialization of science": the Court, with its judicial authority, employs the BOP in a way which defines and constructs its own version of science ${ }^{11}$ to deliver a definite answer to litigants. Yet, as long as the Court plays the role of Hercules by handing down actuarial justice on issues of high controversy, such as risks and science, whatever decision it makes will hardly satisfy the parties concerned, at least the losing party, and thus never fully resolving their disputes. This dichotomy between the Court's transcendental judgment and parties' obsession with their own versions of science is a fundamental factor which threatens both the legitimacy and effectiveness of the Court. Parties, and observers, will neither respect nor fully implement such decisions.

Against this depressing backdrop, this Article explores a new hermeneutical path by which the Court can avoid this potential legitimacy crisis. If the Court's own answer (substantive justice) cannot put an end to parties' antimonial struggle, the Court should contemplate guiding parties to discover the solution between them via constructive regulatory dialogue. In other words, the Court, instead of throwing out its own "right answer" in front of already dogmatic parties, might encourage them to fulfill their dialectical dialogue through talking to, deliberating with, and enlightening each other. This nuanced judicial posture can greatly mitigate any unnecessary adversarial tensions,

\footnotetext{
${ }^{9}$ See Bin CHENG, General PRINCIPLES of LAW As APPlied by InTERNATIONAL COURTS AND Tribunals 327, 334 (1953); Temple of Preah Vihear (Cambodia v. Thail.), 1962 I.C.J. 6, 15-16 (June 15).

${ }^{10}$ Appellate Body Report, US-Wool Shirts and Blouses from United States-Measures Affecting Imports of Woven Wool Shirts and Blouses from India India, 15, WT/DS33/AB/R (April 25, 1997).

${ }^{11}$ In this Article, the notion of science is a broad one, including not only natural science but also social science, such as public policy, sociology, psychology, and economics.
} 
which will in turn secure a certain space for accommodation or recognition of different regulatory positions. ${ }^{12}$

The Court can achieve this new goal by transforming its current substantive hermeneutics over the BOP into a "procedural" one. The Court can lead parties to present different probative evidence, i.e., evidence substantiating the procedural integrity of a measure, from the conventional one, i.e., evidence adduced to prove that it is scientifically valid. For example, if a defending (regulating) party has failed to respond to a complaining (exporting) party's inquiries on the former's new health regulation which is negatively affecting the latter's exports, the Court may establish a presumption against the former that its measure was adopted without valid scientific justification. This jurisprudence will motivate the former to engage with the latter in good faith to avoid any adverse inferences.

A procedural turn by the Court would, in a sense, be redemptive to disputants because it would engage them in a dialectical bond of regulatory discourse and thus immunize them from any zero-sum ruling, which would widen their initial antimonial stance, rather than narrowing it. ${ }^{13}$ In this procedural approach, a Court's decision on risk regulations ${ }^{14}$ is inherently provisional. Even after the decision, parties may still be able to reach a compromise as they naturally engage in further regulatory dialogue as the losing party complies with such procedural decisions whose remedies are also procedural. Critically, the Court does not provide any "final normative standpoint." 15 Instead, it de facto remands the original case to parties with nuanced instructions to communicate with each other in an attempt to overcome their own socio-cultural prejudices on risks and regulation. ${ }^{16}$ This hermeneutical turn to a procedural discipline in fact corresponds with the original normative orientation of those rules which govern risk regulations, i.e.,

${ }^{12}$ In this context, Gaskin observed that "[t]he strategic power of polarized argumentation will always deliver short-term benefits to successful advocates, thereby strengthening popular reliance on transcendental reasoning. Over the longer term, however, dialectical reasoning offers everyone a less divisive accommodation with arguments-from-ignorance by limiting their authority to restricted domains within a broader conceptual horizon." GASKIN, supra note_, at 240.

13 "Rather than bringing conflicts to a peaceful result, contemporary tribunals appear to sharpen existing divisions, even as jurisprudential authority descends from its transcendental abode and shapes the everyday world according to the demands of litigation." GASKIN, supra note_, at 208.

${ }^{14}$ This article focuses on risk regulations under the General Agreement of Tariffs and Trade Article XX (General Exceptions), the Agreement on Technical Barriers to Trade (TBT), the Agreement on Sanitary and Phytosanitary Measure (SPS) which require governments to assess, determine and manage those risk-related regulatory challenges. Those regulations vary in accordance with different types of societal risks, including human health risks and other risks from illicit practices, such as smuggling and tax evasion. Those risk regulations somehow involve scientific investigations in that regulators weigh in risks and effectiveness of policy options by means of objective disciplines, such as toxicology, medical science, engineering, economics, and public health studies. Finally, a disclaimer: this article addresses the BOP issues related to risk-related regulations in the areas of health, safety, environment, and other public policies. It does not deal with the $\mathrm{BOP}$ issues in other areas, such as antidumping law, which have a quite different set of rules and jurisprudence.

${ }^{15}$ GASKIN, supra note_, at 242.

${ }^{16}$ GASKIN, supra note_, at 264. 
GATT Article XX and the SPS Agreement. The preambular language (chapeau) of GATT Article XX focuses on the manner in which a measure is applied. Also, obligations under the SPS Agreement, such as the risk assessment requirement, focus more on regulatory procedures than on substantive, specific levels of protection. ${ }^{17}$

This Article unfolds in the following sequence: Part I launches the analysis by observing that the conventional notion of the BOP in international trade law is the parties' burden. Which one should prove disputed facts has been a subject of serious arguments by parties, which have regarded this issue as a determinative factor to the outcome of their cases. In contrast, Part II shifts the focus from parties to the Court and attempts to conceptualize the BOP as the Court's hermeneutical burden under which the Court must determine who to prove, what to prove and whether to prove before it finally picks the winner in each case. Part III then unearths the Court's veiled agenda beneath the current exercise of its burden. It defines the agenda as "judicialization of science" and argues that the Court plays the role of a Hercules who delivers right answers once and for all on controversial risk-related disputes under its judicial authority. Part IV criticizes this substantive finality which the Court pursues: it not only precipitates jurisprudential incoherencies but also eventually undermines the Court's legitimacy. As a solution, Part $\mathrm{V}$ suggests that the Court should interpretively reconstruct relevant provisions from a procedural standpoint, and thus motivate parties to engage in regulatory dialogue and cooperation. It concludes that the Court should articulately speak to parties through this new hermeneutics.

\section{Parties' Burden: The Conventional Approach on the Burden of Proof in International Trade Law}

The panel practice under the GATT centers on the assignment issue (who to prove) in administering the BOP. ${ }^{18}$ Under the GATT system, panels developed a BOP doctrine despite the lack of any textual ground. ${ }^{19}$ Under this doctrine, a complaining party must demonstrate that a defending party had violated certain provisions of the Agreement. ${ }^{20}$ Also, a party invoking an exception bears the burden of proving that it had

${ }^{17}$ David G. Victor, The Sanitary and Phytosanitary Agreement of the World Trade Organization: An Assessment After Five Years, 32 N.Y.U.J. INT'L L. \& POL. 865, 925-26 (2000).

${ }^{18}$ See Philip M. Nichols, GATT Doctrine, 36. VA. J. INT' L. 379, 434 n.318 (1996) (viewing that "burden of proof is used in the sense of assigning which party is responsible for proving or disproving a proposition rather than in the sense of what "degree of proof that party is required to satisfy"). But see Vern R. Walker, Keeping the WTO from Becoming the "World Trans-Science Organization": Scientific Uncertainty, Science Policy, and Fact-finding in the Growth Hormones Dispute, 31 CoRNELL INT'L L.J. 251, $290-96$ (1998) (distinguishing between the issue of allocation of proof burdens and standard of proof).

${ }^{19}$ Nichols, supra note _, at 434.

${ }^{20}$ See e.g., Canada/Japan--Tariff on Imports of Spruce, Pine, Fir (SPF) Dimension Lumber, 36 Supp. BISD 167, 198 (1989). See also Daniel A. Farber \& Robert E. Hudec, Free Trade and the Regulatory State: A 
met all the requirements of that exception. ${ }^{21}$ Philip Nichols observed that GATT panels took this assignment of the proof burdens on exceptions so seriously that "changing it would be tantamount to renegotiating the obligations and benefits of the Contracting Parties." 22 In articulating the doctrine, GATT panels highlighted that it must be parties', not the panel's, task to demonstrate and prove their arguments and positions. ${ }^{23}$

The WTO inherited from GATT this conventional approach on the BOP which highlights the allocation of the initial burden of proof, i.e., who bears the proof burdens in the first place. ${ }^{24}$ The $\mathrm{AB}$ in Shirts and Blouses delivered a paradigmatic ruling in this issue. The AB held that:

[I]t is a generally-accepted canon of evidence in civil law, common law and, in fact, most jurisdictions, that the burden of proof rests upon the party, whether complaining or defending, who asserts the affirmative of a particular claim or defense. If that party adduces evidence sufficient to raise a presumption that what is claimed is true, the burden then shifts to the other party, who will fail unless it adduces sufficient evidence to rebut the presumption. ${ }^{25}$

This finding has frequently been cited ever since in subsequent cases involving the $\mathrm{BOP}$ issues. ${ }^{26}$ The WTC often begins its ruling on the BOP by referring to the finding.

GATT's-Eye View of the Dormant Commerce Clause, 47 VAND. L. REV. 1401, 1420-21 (1994) (noting that the explicit terms of GATT Article XX requires defendant governments to raise justification).

${ }^{21}$ See e.g., United States--Measures Affecting Alcoholic and Malt Beverages, 39 Supp. BISD 206, 282 (1992); Canada--Import Restrictions on Ice Cream and Yoghurt, 36 Supp. BISD 68, 84 (1989); Canada-Administration of the Foreign Investment Review Act, 30 Supp. BISD 140, 164 (1984).

${ }^{22}$ Nichols, supra note _, at 435.

${ }^{23}$ Nichols, supra note _, at 434; See EEC--Quantitative Restrictions Against Imports of Certain Products from Hong Kong, 30 Supp. BISD 129, 138 (1983).

${ }^{24}$ See Peter Lichtenbaum, Procedural Issues in WTO Dispute Resolution, 19 Mich. J. INT'L L. 1195, 1248 (1998) (regarding the burden of proof issue as whether a complaining party always bears the burden of proof in the WTO dispute proceeding or whether such burden may shift to a defending party under certain conditions).

${ }^{25}$ Appellate Body Report, United States-Measures Affecting Imports of Woven Wool Shirts and Blouses from India, pt. IV, WT/DS33/AB/R (April 25, 1997). Some commentators distinguish between an initial allocation of BOP (global BOP) and a shifted one (local BOP). Regarding views that the BOP is never shifted, see Joost Pauwelyn, Evidence, Proof, and Persuasion in WTO Dispute Settlement: Who Bears the Burden?, , 252-53 (1998) (hereinafter Pauwelyn, Evidence, Proof and Persuasion) (viewing that a complainant's duty to establish a prima facie case subject to a subsequent rebut by a defendant does not regard the burden of proof but the evaluation of evidence and therefore the initial allocation of burden is never shifted); Walker, supra note _, at 295 (arguing that against the burden of persuasion is never shifted onto the defending party, even after the complainant has made its prima facie case).

${ }^{26}$ See e.g., Appellate Body Report, European Communities-Measures Concerning Meat and Meat Products (Hormones), ๆ40, WT/DS26/AB/R (Jan. 16, 1998); Appellate Body Report, European CommunitiesTrade Description of Sardines, I27, WT/DS231/AB/R (Sept. 26, 2002). 
Such habitual citation by subsequent tribunals conferred the finding a certain aura of authority and thus established an observable jurisprudence in this area.

Then why have parties taken the initial allocation of the BOP so seriously? One might reasonably speculate that an initial allocation of proof burdens would eventually determine the outcome of a case since it reflects a normative configuration of treaty obligation, e.g., whether a provision offers an independent right or a mere exception, between a regulating party and the other affected party. ${ }^{27}$ Therefore, a complaining party, like India in Shirts and Blouses, would resist bearing the burden of proving that a defending party, the United States in this case, has violated WTO norms in the first place, but rather prefer to have the defending party bear the burden of proving that the latter's measure could be justified as an exception to certain general obligations.

Treaty texts tend to play an initial, albeit provisional, key role in this normative configuration between parties. By specifying rights and obligations of parties, treaty texts establish various "presumptions" on one side and in turn require the other side to overturn (refute) such presumptions by proving the opposite facts. For this reason, an initial allocation of $\mathrm{BOP}$ is tantamount to declaring an opening position which may be advantageous to one party vis-à-vis the other. Moreover, if an initial burden of proof borne by one party, be it a complaining party or a defending party, is so heavy that the party is likely to fail to discharge its proof burden, such allocation of BOP tends to decide the outcome of a case. Thus, in an adversarial battle of litigation, this original position may be "prominent," in particular when a dispute involves complicated factual aspects such as risks and science. ${ }^{28}$

For example, the Cartagena Protocol is said to create a presumption of danger and thus shift the burden of proving that living modified organisms (LMOs) are safe to an innovator (exporter) ${ }^{29}$ Thus, an importing country, i.e., a regulating country, holds a right to regulate over the importation of the LMOs. Under this normative configuration, an importing (regulating) country's measure will always prevail, if an exporting country's burden to prove its LMOs' safety is insurmountable. Likewise, the SPS Agreement arguably establishes a presumption that a WTO member has a right to set its own appropriate level of sanitary protection, even though such level departs from international standards. As a result, the other party (exporting country) would have to bear the burden

${ }^{27}$ Cf. Linda Hamilton Krieger, The Burden of Quality: The Burden of Proof and Presumption in Indian and American Civil Rights Law, 47 AM. J. COMP. L. 89, 92 (1999) (observing that certain modern Indian laws attempted to employ presumptions and burdens of proof as a "tool for countering the traditional normative system's resistance to the implementation of the new legal regime").

${ }^{28}$ Joost Pauwelyn, The WTO Agreement on Sanitary and Phytosanitary (SPS) Measures as Applied in the First Three SPS Disputes, 2 J. INT'L ECON. L. 641, 659 (1999).

${ }^{29}$ Convention on Biological Diversity, Cartagena Protocol on Biosafety, 29 Jan 2000, U.N. Doc. $\mathrm{UNEP} / \mathrm{CBD} / \mathrm{ExCOP} / 1 / 3$ (June 29, 2000), available at http://www.biodiv.org/biosafety/protocol.asp; Doaa Abdel Motaal, Is the World Trade Organization Anti-Precaution?, 39 J. WORLD TRADE 483, 489-90 (2005). See also Paulette Stenzel, Why and How the World Trade Organization Must Promote Environmental Protection, 13 Duke ENVTL. L. \& POL'Y F. 1, 44 (2002) (contending that the WTO should espouse the precautionary principle and thus impose the burden of proof on manufacturers to demonstrate the safety of a product). 
of proving that the importing country's measure is without scientific justification. However, under the GATT structure, the importing country, not the exporting country, should demonstrate as an exception that such regulation is necessary to protect human health since GATT is premised on free trade obligations by members, not on their rights to regulate. ${ }^{30}$

\section{The World Trade Court's Burden: Reconstructing the Burden of Proof in International Trade Law}

\section{A. From Parties' Burden to the Court's Burden}

As discussed above, the conventional BOP rule under the GATT/WTO jurisprudence imposes an initial BOP on a party invoking certain facts and arguments in its favor. In most cases, the BOP is borne to a complaining party which should demonstrate, or establish a prima facie case, that a defending party has violated GATT/WTO rules. As for exceptions or affirmative defenses, a defending party bears the burden of proving that its measure, although provisionally WTO-inconsistent, nevertheless falls within the rubric of one of the exceptions and thus eventually WTOconsistent. Therefore, under the conventional approach, the BOP denotes parties' burden.

Accordingly, in any adversarial form of adjudication, including the WTO dispute settlement system, the issue of the initial allocation of the BOP appears a momentous matter at first glance. Theoretically, if there was insufficient evidence which substantiates neither party's position or if both parties' evidence is in a state of equipoise in their probative force, the BOP, like a tie-breaker, decides who should win. ${ }^{31}$ In other words, the $\mathrm{BOP}$ may stand for a risk of non-persuasion. In addition, a party which bears the BOP should invest in a substantial amount of time and effort in adducing relevant and necessary evidence in the first place. This initiation cost may be disadvantageous in a strategic sense under an adversarial proceeding.

Under these circumstances, the BOP may be prone to abuse and manipulation. Parties may be tempted to craft their claims in a way that would evade those issues as to which they would not desire to bear the proof burden and force the opposing party to raise and prove those facts. ${ }^{32}$ One commentator observed that there is a "genuine risk"

${ }^{30}$ See e.g., Appellate Body Report, United States-Standards for Reformulated and Conventional Gasoline, 22-23, WT/DS2/AB/R (Apr. 29, 1996); Appellate Body Report, United States-Measures Affecting Imports of Woven Wool Shirts and Blouses from India, 14-15, WT/DS33/AB/R (April 25, 1997); Panel Report, United States-Section 337 of the Tariff Act of 1930, 95.27, WT/DS186/R (Jan. 12, 2000).

${ }^{31}$ Michael Lennard, Navigating the Stars: Interpreting WTO Agreements, 5 J. INT'L. ECON. L. 17, 84 (2002)

${ }^{32}$ Michelle T. Grando, Allocating Burden of Proof in WTO Disputes, 9 J. INT'L ECON. L. 615, 629 (2006). 
that parties do nothing in the proceedings but claim that the other party should persuade the panel. ${ }^{33}$

On the other hand, however, it is eventually the Court which decides who should win. The initial allocation of the BOP (who to prove) alone seldom decides the outcome of a case. This issue may be of great importance under the common law system where judicial interventions are seriously curtailed by the existence of jury and litigant autonomy, even in case of evidential incompleteness. ${ }^{34}$ Yet, its relative significance tends to wane in international tribunals since these tribunals hold a wider range of discretion in the proceeding and emphasize a collective obligation by parties to cooperate with each other in presenting evidence before the tribunals. ${ }^{35}$ The WTC is no exception to this trend in that it enjoys wide discretion in fact-finding, including the authority to summon expert witnesses. ${ }^{36}$

As an ostensible departure from the law and economic analysis, the BOP rule under the WTO system does not reflect "respective difficulties that may possibly be encountered by the complainant and the respondent in collecting information to prove a case. ${ }^{37}$ Instead, winning or losing a case hinges critically on how the Court itself interprets both facts and law in proof-related areas, i.e., whether to prove and what to prove. It is the Court which weighs each evidence and determines whether and how much a party has proved to discharge its BOP as well as when to shift the proof burden to the other party. The Court enjoys "a margin of discretion in assessing the value of the evidence, and the weight to be ascribed to that evidence. ${ }^{38}$ This discretion is immune from an appeal..$^{39}$ The Court may even consider the expert opinions to determine whether

${ }^{33}$ Pauwelyn, Evidence, Proof and Persuasion, supra note , at 228-29.

${ }^{34}$ See Dale A. Nance, Evidential Completeness and the Burden of Proof, 49 Hastings L. J. 621, 640 (1998).

${ }^{35}$ Grando, supra note, at 616 n.2.. See also Mojtaba KazAzi, Burden of Proof ANd Related ISSUES: A STUDY ON EVIDENCE BEFORE INTERNATIONAL TRIBUNALS 119 (1996); "It is often said that the idea of peaceful settlement of disputes before international tribunals is largely based on the premise of cooperation of the litigating parties." Pauwelyn, Evidence, Proof and Persuasion, supra note_, at 234 (quoting Appellate Body Report, Argentina - Measures Affecting Imports of Footwear, Textiles, Apparel, and Other Items, I6.40, WT/DS56/R (Nov. 25, 1997)). See also Claus-Dieter Ehlermann, Six Years on the Bench of the "World Trade Court": Some Personal Experiences as Member of the Appellate Body of the World Trade Organization, in The WTO DisPute SeTtLement System 1995-2003 499, 511(Federico Ortino and Ernst-Ulrich Petersmann eds., 2004) (observing that the issue of the burden of proof has seldom been raised in the European Court of Justice).

${ }^{36}$ But see Robert Howse \& Petros C. Mavroidis, Europe's Evolving Regulatory Strategy for GMOs-The Issue of Consistency with WTO Law: Of Kine and Brine, 24 FORDHAM INT'L L. J. 317, 346 (2000) (arguing that a panel's use of expert witnesses in the WTO proceeding should be limited to convincing themselves of an already proved prima facie case, but not be extended to substantiating such facts as were not presented by parties).

37 Appellate Body Report, European Communities-Trade Description of Sardines, I281, WT/DS231/AB/R (Sept. 26, 2002).

${ }^{38}$ Appellate Body Report, European Communities-Measures Affecting Asbestos and Products Containing Asbestos, $₫ 161, \mathrm{WT} / \mathrm{DS} 135 / \mathrm{AB} / \mathrm{R}$ (Mar. 12, 2001).

39 Appellate Body Report, Australia-Measures Affecting the Importation of Salmon, I261, WT/DS18/AB/R (Oct. 20, 1998) ("The Panel's consideration and weighing of the evidence in support of 
a prima facie case has been established..$^{40}$ Likewise, it is the Court which decides what should be proved, i.e., the question of "what the importing Member must demonstrate."

For example, in Gambling both the defendant (the United States) and the complainant (Antigua) appealed on the ground that the panel erred in its treatment of BOP under GATS Article XIV (General Exceptions). Interestingly, both the U.S. and Antigua argued that the panel, in deciding whether the United States' ban on the online gambling was an "arbitrary or unjustifiable discrimination," failed to base its ruling on the other party's arguments and evidence adduced in terms of Article XIV, but instead "recycled" previous arguments and evidence submitted by both parties under different provisions. ${ }^{42}$

To each party this recycling by the panel is improper since it unduly advantaged the other party. Antigua viewed that the recycling permitted the United States to discharge the latter's initial burden of making a prima facie case under the exception clause (Article XIV) when the latter failed to do so. ${ }^{43}$ On the other hand, the United States submitted that the same practice (recycling) "constructed a rebuttal" under the chapeau (arbitrary and unjustifiable discrimination) in favor of Antigua when Antigua failed to do so. ${ }^{44}$ However, the Appellate Body (AB) endorsed the panel's discretion to reuse those arguments and evidence previously adduced under different yet still relevant provisions. ${ }^{45}$ This overarching evidentiary rule, although it may contribute to judicial economy, tends to override the initial allocation of $\mathrm{BOP}$ by allowing the panel to effectively relieve a certain party of its BOP.

I am not arguing here that the initial allocation of burden of proof (who to prove) is inconsequential. It is still important. As Henrik Horn and Joseph Weiler aptly observed, it will "ceteris paribus affect the probability that the different parties win" by burdening one party over the other. ${ }^{46}$ Likewise, it will shape Members' behavior in various ways, including their resource spending in the proceeding as well as decision-making as to whether to launch litigation at all and/or when to settle. ${ }^{47}$ Nonetheless, such determinant power of the allocation of BOP tends to dramatically decrease if the very "ceteris paribus" (other things being equal) condition is not met. In other words, if the Court destabilizes

Canada's claims relates to its assessment of the facts and, therefore, falls outside the scope of appellate review under Article 17.6 of the DSU.")

${ }^{40}$ Appellate Body Report, India - Quantitative Restrictions on the Imports of Agriculture, Textile, and Industrial Products, ๆ142, WT/DS90/AB/R (Aug. 23, 1999).

${ }^{41}$ Appellate Body Report, United States-Measures Affecting Imports of Woven Wool Shirts and Blouses from India, 14-15, WT/DS33/AB/R (April 25, 1997)

${ }^{42}$ Appellate Body Report, United States-Measures Affecting the Cross-Border Supply of Gambling , ๆๆ 277-79, WT/DS285/AB/R (Apr. 7, 2005).

${ }^{43} \mathrm{Id}$. at $₫ 278$.

${ }^{44} \mathrm{Id}$. at 9279 .

${ }^{45} \mathrm{Id}$. at $\mathrm{9}$ ฯ $287-88$.

${ }^{46}$ Henrik Horn and Joseph H.H. Weiler, European Communities - Trade Description of Sardines: Textualism and its Discontent, in THE WTO CASE LAW OF 2002262 (H. Horn and P.C. Mavroidis eds. 2005).

${ }^{47} \mathrm{Id}$. 
this unique condition by setting the subsequent terms of parties' evidentiary tasks, i.e., whether to prove and what to prove, the initial allocation (locus) of BOP, i.e., who to prove, may not matter much after all.

For example, in Hormones, even if the $\mathrm{AB}$ viewed that "the Panel mistakenly required that the European Communities take on the burden of proof that its measures related to the hormones involved here, except MGA, are based on a risk assessment," and therefore determined that "the United States and Canada have to make a prima facie case that these measures are not based on a risk assessment," the AB still found that "the United States and Canada, although not required to do so by the Panel, did, in fact, make this prima facie case that the SPS measures related to the hormones involved here, except MGA, are not based on a risk assessment."48

More saliently, the AB in Sardines addressed the effectiveness and appropriateness of an international standard (Codex Stan 94) on the labeling of Sardines under the Agreement on Technical Barriers to Trade (TBT). ${ }^{49}$ The EC's Regulation monopolized the use of term "Sardine" in favor of those sardines caught in the European sea in the name of consumer protection, while the Codex standard explicitly endorsed a much more liberal, generic use of the term. Therefore, the labeling of Peruvian Sardines was prohibited by the EC Regulation, which departed from the Codex Stan 94 permitting such labeling. Article 2.4 of TBT requires Members to follow a relevant international standard unless it is ineffective and inappropriate in achieving putative regulatory goals. Who should then bear the initial burden of proving that the Codex standard is still ineffective and inappropriate?

The Panel viewed that the defendant (the EC) should, while the $A B$ viewed that it should rest on the complainant (Peru). The $A B$, in tandem with its similar ruling in Hormones, emphasized that Members enjoy regulatory autonomy which would include even a right to disregard a relevant international standard if it believes that such standard is ineffective and inappropriate. Therefore, according to the $\mathrm{AB}$, Peru should have proved that Codex Stan 94 was in fact effective and appropriate to fulfill the EC's regulatory goals. At first blush, Peru's BOP seems quite heavy since it should produce positive (apodeicdic) evidence which would substantiate that Codex Stan 94 could fully address European consumers' concerns for fraud and confusion over sardines.

Nonetheless, the AB declared that Peru did discharge its apparently formidable $\mathrm{BOP}$ by applying rather light evidentiary criteria. Both the panel and the $\mathrm{AB}$ endorsed Peru's negative (apagogical) evidence which illustrated that "it has not been established" that most European consumers "have always associated the common name 'sardines'

\footnotetext{
${ }^{48}$ Appellate Body Report, European Communities-Measures Concerning Meat and Meat Products (Hormones), ๆ197 n.180, WT/DS26/AB/R (Jan. 16, 1998).

49 Appellate Body Report, European Communities-Trade Description of Sardines, II284-91, WT/DS231/AB/R (Sept. 26, 2002).
} 
exclusively with Sardina pilchardus" which are those sardines harvested in the European sea and thus familiar to European consumers. ${ }^{50}$

This type of evidence seems quite insufficient to discharge Peru's seemingly heavy $\mathrm{BOP}$ since there could still be some confused European consumers out there and the EC might pursue a zero-tolerance policy over consumer protection, as it did in Hormones. ${ }^{51}$ In other words, the AB's hermeneutics on this low evidentiary threshold in proving whether an international standard is efficient or appropriate amounts to a second-guessing of Members' level of regulatory protection. The $\mathrm{AB}$ insinuated that given the regulatory environment in which to its belief no significant level of risks from consumer confusion over sardines existed, the Codex Stan 94 would be good enough after all. This posture runs in the face of the AB's previous allocation of $\mathrm{BOP}$ in favor of Members' regulatory autonomy, which led Peru, not the EC, to prove the value of Codex Stan 94. Accordingly, the AB's reversal of the panel's allocation of $\mathrm{BOP}$ (who to prove) from a defendant (the EC) to a complainant (Peru) in the spirit of regulatory autonomy failed to deliver any impact due to the AB's subsequent prescription of a low evidentiary threshold in discharging Peru's BOP (whether to prove). ${ }^{52}$

The Court's subsequent dilution of any impacts which the initial allocation of the BOP might have delivered through lessening the evidentiary threshold, standards of proof, in Sardines testifies that the BOP issues are "hermeneutical" in nature. It is in the Court's interpretive discretion, ${ }^{53}$ or more critically, prudence, to resolve who to prove, whether to prove and what to prove in each dispute on a case-by-case basis. Even the conventional focal point, i.e., who to prove, is subject to this interpretive discretion because in most cases the allocation of an initial BOP is not obvious from the text itself and often requires the Court's creative construction. This interpretive task concerning the BOP eventually becomes the Court's own responsibility or burden under the DSU in that the task falls within the realm of "an objective assessment of the facts of the case and the applicability of and conformity with the relevant covered agreements." ${ }^{54}$ In the end, how the Court discharges this burden determines not only the destiny of a given case but also the legitimacy of the Court.

${ }^{50} \mathrm{Id}$. at $\$ 290$ (underlining added).

${ }^{51}$ See Horn \& Weiler, supra note_, at 272.

${ }^{52}$ See Veijo Heiskanen, The Regulatory Philosophy of International Trade 38 J. WORLD TRADE 1, 31(2004) (viewing that the AB's reversal of the Sardine panel's ruling on the allocation of the burden of proof "had no effect on the outcome of the case").

${ }^{53}$ Cf. Pauwelyn, Evidence, Proof and Persuasion, supra note _, at 227 (referring to "a tool which is particularly attractive to adjudicators: clouded in an air of procedural neutrality but, by the same token, falling to a considerable extent within the quasi-discretionary powers of the panel").

${ }^{54}$ Understanding on Rules and Procedures Governing the Settlement of Disputes, Apr. 15, 1994, Marrakesh Agreement Establishing the World Trade Organization, Annex 2, Legal Instruments-Results of the Uruguay Round, 33 I.L.M. 112, 120 (1994) (hereinafter DSU). But cf. Walker, supra note_ . (submitting that the Appellate Body should impose on panels a minimum requirement of "rational inference," defined as "minimal evidence that any reasonable person would consider necessary to support such a finding," namely a "preponderance standard of proof"). 
This hermeneutical burden appears more salient to the WTC than to domestic courts. International agreements, such as the SPS Agreement, are essentially a product of compromise after a series of negotiations, which expounds the inherent ambiguity of their texts. ${ }^{55}$ To project a WTO Member's concrete (contextualized) behavior (an alleged violation) onto these abstract (de-contextualized) texts necessitates panels' or the AB's creative (re-) construction of these texts beyond mechanical application of them. Although it is WTO members themselves which ultimately (re-) interpret them in a legislative sense, ${ }^{56}$ to resolve a dispute through the aforementioned (re-) construction is reserved to a panel or the $A B$.

Finally, the court-oriented approach to the BOP proposed here is more amenable to the practical reality than the conventional, party-oriented approach. The BOP, in a conventional narrow sense, only concerns facts, not law. Matters of law are decided exclusively by judges (jura novit curia). Parties bear no BOP as to issues of law even though they often present legal arguments in their favor ${ }^{57}$ However, in practice the line between law and facts is blurred. Factum probandum is often enmeshed in legal claims and arguments. Under the court-oriented approach, the Court tends to correspond better with this blurred distinction since it may feel less compelled to dichotomize facts and law for the purpose of the BOP. After all, the Court interprets both facts and law.

\section{B. Three Hermeneutical Burdens of the Court}

\section{Who to Prove}

As discussed above, parties may not predict precisely who will bear the proof burden in advance since it is basically a matter of the Court's interpretation. ${ }^{58}$ For example, Article 5, paragraph 10 of the SPS Agreement establishes that an SPS measure conforming to international standards is presumed to be consistent with relevant SPS provisions. One might interpret this provision as imposing the $\mathrm{BOP}$ on a regulating

${ }^{55}$ See notably John H. Jackson, Appraising the Launch and Functioning of the WTO, 39 GERMAN Y. B. INT'L L. 20, 39 (1996) (viewing that "the decision-making and voting procedures of the WTO, although much improved over the GATT, still leave much to be desired"); John H. Jackson, International Economic Law in Times That Are Interesting, 3 J. INT'L ECON. L. 3, 8 (2000) (viewing that "treaties are often an awkward albeit necessary method of designing institutions needed in today's interdependent world, but they do not solve many problems").

${ }^{56}$ Final Act Embodying the Results of the Uruguay Round of Multilateral Trade Negotiations, Annex 1A, Apr. 15, 1994, 33 I.L.M. 1125, 1148 (1994) (hereinafter WTO Agreement) ("The Ministerial Conference and the General Council shall have the exclusive authority to adopt interpretations of this Agreement and of the Multilateral Trade Agreements.").

${ }^{57}$ Pauwelyn, Evidence, Proof and Persuasion, supra note _, at 242.

${ }^{58}$ Peter Lichtenbaum, Procedural Issues in WTO Dispute Resolution, 19 MICH. J. INT'L L. 1195, 1252 (1998). 
(defending) party in case it fails to enjoy such presumption. ${ }^{59}$ In this line, the Hormones panel ruled that the EC should demonstrate that its ban on hormoned beef would still be necessary, although the ban departed from the Codex standard, since the standard was not good enough for the purpose of the EC's regulation. In other words, the existence of the presumption would construct members' duty to follow international standards under Article 3.1 as a general obligation and an opt-out clause under Article 3.3 as an exception. ${ }^{6}$

However, this position was patently rejected by the $A B$, which instead interpreted the same provision in a diametrically opposite fashion. The $A B$ attempted to legitimize its opposite interpretation from a textual ground, although a reasonable inference from the text (Articles 3.1 and 3.3) would lead to the panel's original interpretation. The AB simply renounced the general obligation/exception relationship in Articles 3.1 and 3.3, upholding members' regulatory autonomy which may even encompass a right to depart from international standards despite an explicit obligation to follow those standards under Article 3.1. ${ }^{61}$ The $\mathrm{AB}$ held that:

We cannot lightly assume that sovereign states intended to impose upon themselves the more onerous, rather than the less burdensome, obligation by mandating conformity or compliance with such standards, guidelines and recommendations. ${ }^{62}$

To the $\mathrm{AB}$, harmonization of SPS measures through international standards under Article 3.1 merely embodies an aspiration, not a legal obligation, which is "yet to be realized in the future." ${ }^{63}$

Critically, these diverging interpretive postures between the panel and the $A B$ are attributable to more than textual grounds. They represent different institutional objectives and purposes (teloi) which the panel and the $\mathrm{AB}$ project to the text whenever they interpret it. These different teloi reflect different Zeitgeists shaping the development of international trade law.

One of the principal criticisms directed to the GATT was its embedded pro-trade bias. Founded against the historical background of economic balkanization in the interwar period, the original teleology of the GATT was free trade. Although it did recognize certain compromise by permitting non-trade values, such as protection of human health or the environment, these values were upheld only as "exceptions" under

${ }^{59}$ See John J. Barcelo III, Product Standards to Protect the Local Environment-The GATT and Uruguay Round Sanitary and Phytosanitary Agreement, 27 CORNELL INT'L L.J. 755, 774 (1994).

${ }^{60}$ Panel Report, European Communities-Measures Concerning Meat and Meat Products (Hormones), ฯศ 8.86-8.87, WT/DS26/R (Aug. 18, 1997).

${ }^{61}$ Appellate Body Report, European Communities-Measures Concerning Meat and Meat Products (Hormones), $\boldsymbol{\uparrow} \uparrow 169-171, \mathrm{WT} / \mathrm{DS} 26 / \mathrm{R}$ (Jan. 16, 1998).

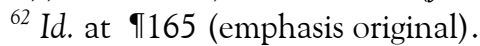

${ }^{63} \mathrm{Id}$. (emphasis original). 
Article XX. In other words, these values were only secondary to the main value of free trade, represented by basic obligations, such as the National Treatment principle. ${ }^{64}$

Furthermore, these values were very hard to recognize in a practical sense since exceptions are meant to be interpreted narrowly, not broadly. In fact, in the entire GATT history, not a single non-trade value was upheld under Article XX. ${ }^{65}$ Under this pro-trade bias which structurally downgrades non-trade values as exceptions, a burden of proving that any given regulation is legitimate (non-protectionist) and necessary rests on a regulating country. One might justify this position by observing that any regulation is presumed to be protectionist since any government tends to favor its domestic producers in designing the regulation. ${ }^{66}$

Unsurprisingly, this structural and empirical pro-trade bias of the GATT regime drew much criticism from both environmentalists and domestic regulators. A number of NGOs have vehemently attacked the neo-liberal mantra of free trade-cum-globalization which they believe undermines more paramount values such as environmental protection or social justice. In addition, the rise of the modern welfare state, which is expected to respond to citizens' heightened demands for better social hygiene, turned a once deregulatory ethos to a re-regulatory one. This elevated recognition of domestic regulations naturally altered the political dynamics around them. In the past, risk regulations were mostly regarded as technical and professional issues which concerned a narrow epistemic community of scientists and policymakers. ${ }^{67}$ However, once highlighted and thus politicized, risk regulations have become everybody's business. ${ }^{68}$

Out of this novel pro-regulation ethos, negotiators in the Uruguay Round created the SPS/TBT Agreement which escalated those non-trade values once regarded as mere exceptions under GATT Article XX to an autonomous "right" to regulate. The TBT preamble recognizes that "no country should be prevented from taking measures necessary ... for the protection of human, animal or plant life or health, of the environment" ${ }^{69}$; SPS Article 2.1 specifies that "Members have the right to take sanitary and

${ }^{64}$ See generally Sungjoon Cho, Free MARKETS And Social Regulation: A Reform AgEnda of THE GLOBAL TRADING SYSTEM (2003).

${ }^{65}$ See Robert Howse, Managing the Interface between International Trade Law and the Regulatory State: What Lessons Should (and Should Not) Be Drawn from the Jurisprudence of the United States Dormant Commerce Clause, in REgUlATORY BARRIERS AND THE PRINCIPLE OF NON-DISCRIMINATION IN WORLD TRADE LAW 142 (Thomas Cottier \& Petros C. Mavroidis eds. 2000).

${ }^{66}$ Kazumochi Kometani, Trade and the Environment: How Should WTO Panels Review Environmental Regulations Under GATT III and XX?, 16 NW. J. INT'L L. \& BUS. 441, 449 (1996).

${ }^{67}$ See Terence P. Stewart \& David S. Johanson, The SPS Agreement of the World Trade Organization and International Organizations: The Roles of the Codex Alimentarius Commission, the International Plant Protection Convention, and the International Office of Epizootics, 26 SYRACUSE J. INT’L L. \& COM. 27, 28 (1998).

${ }^{68} \mathrm{Id}$., at 52.

${ }^{69}$ Agreement on Technical Barriers to Trade, Annex 1A, the WTO Agreement, supra note_, pmbl. (hereinafter TBT). 
phytosanitary measures necessary for the protection of human, animal or plant life or health." 70

Silhouetted against this new ethos valuing regulatory autonomy of member countries, the $\mathrm{AB}$ would put members' right to regulate before voluntary international standards, even though the SPS envisions harmonization around these standards. This value system eventually led the $A B$ to reverse the otherwise plausible interpretation by the Hormones and Sardines panels which imposed on regulating parties the initial burden of proving that these standards were scientifically unjustified or ineffective/inappropriate to achieve their regulatory goals, and instead required the complaining parties to prove that these standards were supported by science and effective/appropriate. ${ }^{71}$

\section{What to Prove}

The second burden of the Court on the BOP is to decide what parties should prove to discharge their $\mathrm{BOP}$. The Court's interpretive orientation in this matter is often embodied in certain doctrinal tests, e.g., three- or four-prong tests. By designing these tests, the Court exercises its hermeneutical power in a way which steers parties' adversarial battle to the direction that it chooses. This aspect of BOP was first raised by the $\mathrm{AB}$ in Shirts and Blouses. The $\mathrm{AB}$ viewed that:

[W]e consider the question of what the importing Member must demonstrate at the time of its determination. ... In the context of the GATT 1994 and the WTO Agreement, precisely how much and precisely what kind of evidence will be required to establish such a presumption will necessarily vary from measure to measure, provision to provision, and case to case. ${ }^{72}$

Although this aspect of BOP has not been salient, at least explicitly, the Court relied heavily on it in moving the proceeding forward. For example, the Hormones panel required the $\mathrm{EC}$ to demonstrate that it actually conducted a risk assessment by itself, proceduralizing the duty to assess risks. ${ }^{73}$ However, the $\mathrm{AB}$ rejected this procedural aspect of risk assessment obligation, leaving only its substantive part. Therefore, the EC only had to demonstrate that there existed a rational relationship between its measure and a risk assessment. ${ }^{74}$ Under this ruling, the EC could have even outsourced its risk assessment.

${ }^{70}$ Agreement on the Application of Sanitary and Phytosanitary Measures, the WTO Agreement, supra note_, art. 2.1 (hereinafter SPS).

${ }^{71}$ See John H. Knox, The Judicial Review of Conflicts Between Trade and the Environment, 28 HARV. ENVTL. L. REV. 1, 43-4 (2004).

${ }^{72}$ Appellate Body Report, United States-Measures Affecting Imports of Woven Wool Shirts and Blouses from India, pt. IV, WT/DS33/AB/R (April 25, 1997) (emphasis added).

${ }^{73}$ Panel Report, European Communities-Measures Concerning Meat and Meat Products (Hormones), ฯ1008, WT/DS26/R (Aug. 18, 1997).

${ }^{74}$ Appellate Body Report, European Communities-Measures Concerning Meat and Meat Products (Hormones), $\llbracket 193$, WT/DS26/AB/R (Jan. 16, 1998). 
Furthermore, according to the $\mathrm{AB}$, a risk assessment need not be based on a mainstream scientific opinion: even a minority opinion is sufficient to justify the risk assessment. ${ }^{75}$

These two interpretations by the $A B$, which were diametrically opposite to those of the panel, would have allowed the EC to rely on serendipitous studies which had come out only after it banned the hormone-treated beef. ${ }^{76}$ In other words, the AB's liberal interpretation on the risk assessment requirement practically reduced the EC's proof burdens because the EC would have easily cherry picked any novel yet controversial scientific opinions and presented them to discharge its proof burdens under Article 5.1. ${ }^{77}$

\section{Whether to Prove}

After the Court decides who should bear the BOP over disputed facts and what exactly parties should prove, its last interpretive task over the BOP is to determine whether parties bearing the proof burdens have actually discharged them. In other words, the Court should resolve the quantum (standard) of proof issue, i.e., how much evidence would be sufficient for a party to establish a prima facie case or to rebut the presumption that the initial prima facie case created in each case. ${ }^{78}$

Therefore, when a complaining party claims that the other party violates Article 2.2 of the SPS Agreement by maintaining its sanitary measure without scientific justification, the complaining party should prove that there is no rational relationship between the defending party's measure and the scientific evidence. After all, the Court will decide whether such a relationship exists "on a case-by-case basis" taking into account the "particular circumstances of the case." "

Likewise, the Salmon panel originally found that the alleged Australian risk assessment on imported salmon (1996 Final Report) "addresse[d] and to some extent evaluate[d] a series of risk reduction factors, in particular, on a disease-by-disease basis." ${ }^{80}$ Accordingly, the panel assumed that the 1996 Final Report did "evaluate the likelihood of entry, establishment or spread of these diseases according to the SPS measures which might be applied" in compliance with Article 5.1 of the SPS Agreement. However, the $\mathrm{AB}$ disagreed. It viewed that "some evaluation of the likelihood is not enough." 81

${ }^{75} \mathrm{Id}$. at $₫ 194$.

${ }^{76}$ Reinhard Quick \& Andreas Blüthner, Has the Appellate Body Erred?: An Appraisal and Criticism of the Ruling in the WTO Hormones Case, 2 J. INT'L ECON. L 603, 615 (1999).

${ }^{77} \mathrm{Id}$. at 618.

${ }^{78}$ Pauwelyn, Evidence, Proof and Persuasion, supra note_, at 233.

${ }^{79}$ Appellate Body Report, Japan-Measures Affecting Agricultural Products, 184, WT/DS76/AB/R (Feb. 22 1999).

${ }^{80}$ Panel Report, Australia-Measures Affecting the Importation of Salmon, 18.91 , WT/DS18/R (June 12, 1998) (emphasis added).

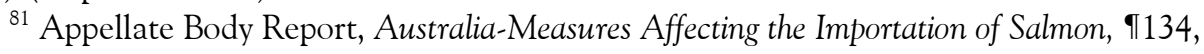
WT/DS18/AB/R (Oct. 20, 1998) (emphasis original). 
Therefore, how much evaluation needs to be shown to discharge the burden of proof regarding risk assessment depends totally on the Court's interpretation under each circumstance.

It was in this way that the $\mathrm{AB}$ in Gambling concluded that the U.S. demonstrated successfully the necessity of its ban on remote gambling, while Antigua failed to identify a reasonably available alternative measure which might have rebutted the U.S. position. ${ }^{82}$ In the same vein, the $A B$ in Korean Beef held that Korea failed to meet its burden of proving that alternatives to the dual retails system were not reasonably available. ${ }^{83}$

Intriguingly, this onus of proof ${ }^{84}$ often plays a face-making function when the Court delivers its final decision. In any WTO dispute, a defending party loses for two reasons. First, it may lose in an "apodeicdic" fashion when the Court finds that its measure has violated, i.e., been inconsistent with, the WTO norms. Second, it may also lose in an "apagogical" fashion when the Court finds that it fails to demonstrate that its measure is not inconsistent with the WTO norms; to wit, it fails to discharge its burden of proving that its measure has not violated the WTO norms. The same logic applies to a situation in which a complaining party loses. It may lose when the Court finds that the measure in question is consistent with the WTO norms; it may also lose when the Court finds that the complaining party fails to establish its prima facie case that the measure is not consistent with the WTO norms.

In both situations, the latter (apagogical) type of finding appears less damaging than the former to the losing party. While the former tends to blatantly reject a party's claim, the latter tends to provisionally suspend the claim in a given dispute. In other words, in the former occasion, a losing party may not confidently make the same claim in any future dispute since it has been struck down. In the latter occasion, however, it may still make the same claim if it comes up with more or better pieces of evidence which may convince the Court. Therefore, the Court may gracefully mitigate the damage of the losing party by attributing its defeat not to a substantive reason (violation) but rather to a technical, procedural failure, even though such differentiation would not change the outcome of the case.

\section{A Cumulative Nature of Three Burdens}

These interpretive burdens that the Court bears in deciding who to prove, what to prove and whether to prove are interrelated and cumulative in nature, and should thus be understood in their entirety. No single aspect alone would be sufficient to capture true hermeneutical attributes of the BOP.

${ }^{82}$ Appellate Body Report, United States-Measures Affecting the Cross-Border Supply of Gambling, १326, WT/DS285/AB/R (Apr. 7, 2005).

${ }^{83}$ Appellate Body Report, Korea-Measures Affecting Imports of Fresh, Chilled and Frozen Beef, 1182 , WT/DS169/AB/R (Dec. 11, 2000).

${ }^{84}$ Horn \& Weiler, supra note_, at 261. 
As discussed above, the conventional focal point in the BOP, i.e., the assignment issue (who to prove), may not be too critical to the outcome of the case because there are hardly any cases where the initial allocation of BOP solely determines the outcome of a litigation absent any prevailing evidence. Moreover, an alternating, ping pong-like shift of $\mathrm{BOP}$ between parties rarely happens. A panel or the $\mathrm{AB}$ simply interprets both facts and law based on a collection of arguments and evidence submitted by both parties as well as other undisputed facts.

Thus, the Court's decision on who to prove may not change the outcome of the dispute. For example, the Sardines panel ruled that a regulating party departing from an international standard should bear the burden of proving that such standard would not be appropriate to the level of protection it pursued. ${ }^{85}$ Although the AB reversed the panel's finding and ruled that the complainants, not defendants, bear the burden of proving that the international standard would be appropriate, such reversal did not change the outcome of the case: the EC still lost since the $\mathrm{AB}$ simply found that the complainant met the proof burden. ${ }^{86}$

In addition, new aspects of BOP, i.e., what to prove and whether to prove, also influence the conventional aspect of BOP, i.e., who to prove. Although a defending party (a regulating party) in general bears the burden of proving that a measure in question was necessary or relating to achieve the putative regulatory goal in terms of an affirmative defense (exception) under GATT Article XX, ${ }^{87}$ the WTC may instead require a complaining party to bear a heavier burden than usual in the preceding stage, i.e., when it establishes a prima facie case that the defending party violated a general obligation such as the National Treatment principle. This heavier standard of proof in an earlier stage on the complaining party tends to relieve the defending party of its own BOP at a later (exception) stage.

For example, the AB in Asbestos held that the complaining party (Canada)'s initial burden of proving that France discriminated against Canadian asbestos in favor of its domestic substitute fibers was a "heavy" one. ${ }^{88}$ This holding reflects the AB's critical observation that the carcinogenic asbestos and risk-free substitute fibers could not be treated alike. ${ }^{89}$ The $\mathrm{AB}$ found that:

"This carcinogenicity, or toxicity, constitutes, as we see it, a defining aspect of the physical properties of chrysotile asbestos fibers. The evidence indicates that PCG

85 Appellate Body Report, European Communities-Trade Description of Sardines, I282, WT/DS231/AB/R (Sept. 26, 2002).

${ }^{86} \mathrm{Id}$. at 315.

${ }^{87}$ See supra pt. I.

88 Appellate Body Report, European Communities-Measures Affecting Asbestos and Products

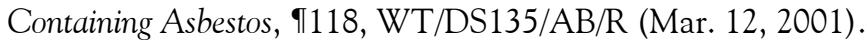

${ }^{89}$ Sydney M. Cone, III, The Asbestos Case and the Dispute Settlement in the WTO: the Uneasy Relationship Between Panels and the Appellate Body, 23 MICH. J. INT'L L. 103, 114-8 (2001). 
fibers, in contrast, do not share these properties, at least to the same extent. We do not see how this highly significant physical difference cannot be a consideration in examining the physical properties of a product as part of a determination of "likeness" under Article III:4 of the GATT 1994."

Here, by incorporating health risks, which concerned GATT Article XX(b), into Article III:4 (National Treatment) consideration, ${ }^{91}$ the AB dramatically increased the complaining party (Canada)'s burden of establishing a prima facie case that Canadian asbestos, which was banned, and French substitute fibers, which were permitted, would be like products and thus deserve equal treatment. In fact, Canada's initial onus of proof which the AB's pro-regulation interpretation increased seemed too heavy for Canada to meet in a practical sense. It would be highly unlikely to expect that Canada would ever persuade the $A B$ into accepting that Canadian asbestos and French substitute fibers are like despite the AB's foregoing risk-driven interpretation on physical properties. As a result, the defending party (the EC) was in effect relieved of its burden to prove that the asbestos ban was necessary to protect human health in France.

Therefore, the AB's escalation, via interpretation, of a probative threshold (standard of proof) not only de facto shifted the burden of proof as to the necessity of the regulation but also created a de facto presumption of regulatory legitimacy which seems practically irrefutable.

A similar reversal of proof burden through the Court's construction of what to prove is found in Japan-Agricultural Products. Under the traditional necessity test under GATT Article XX, the defending party (Japan) would have had to demonstrate that its measure was the least trade restrictive means as an affirmative defense. In this case, however, the $\mathrm{AB}$ ruled that the complaining party (the U.S.) should demonstrate that a reasonable less-restrictive alternative to the regulation in question could have been feasible. ${ }^{92}$

\title{
III. What Lies beneath the World Trade Court's Burden: The Judicialization of Science
}

\author{
A. The Judicial Regulation of Science
}

${ }^{90}$ Appellate Body Report, European Communities-Measures Affecting Asbestos and Products Containing Asbestos, $\uparrow 114$, WT/DS135/AB/R (Mar. 12, 2001) (italics original, underlining added).

${ }^{91}$ SungJOON CHO, supra note.

${ }^{92}$ Appellate Body Report, Japan-Measures Affecting Agricultural Products, ๆ126, WT/DS76/AB/R (Feb. 22 1999). 
Investigating the WTO's jurisprudence on risk regulations (e.g., SPS and TBT measures) under a new paradigm over the BOP, which is shifted from the parties' burden to the Court's burden, enables us to probe the Court's rationale or "value" which may be defined as a set of basic priorities and assumptions around which its hermeneutics operates. Analyzing the jurisprudential track record of the last decade over risk regulations, one might reach a conclusion that the Court has not only adjudicated scientific cases but also judicialized scientific questions. In other words, the Court has rendered definite scientific answers, instead of merely resolving science-related disputes.

This phenomenon of judicialization of science was launched in a paradigmatic case in this area, i.e., Hormones. Originally, the panel in Hormones imposed an initial BOP as to Article 5.5 of the SPS Agreement (the prohibition of arbitrary or unjustifiable discrimination) on the complaining party (the United States). The United States argued that the EC's asymmetrical regulatory treatment between naturally occurring hormones (in meat and other foods) which led to no regulatory intervention at all, and the artificially injected ones for growth promotion purposes which led to a total ban was arbitrary and unjustifiable. ${ }^{93}$ Having assessed the United States' argument, the evidence that it adduced, and the expert opinions, ${ }^{94}$ the panel seemed to find that the initial BOP had shifted to the EC which should rebut what the United States had proven. ${ }^{95}$ The panel held that the EC had not met its BOP. ${ }^{96}$

However, the $\mathrm{AB}$ reversed the panel's finding of the EC's arbitrarily and unjustifiably asymmetrical regulatory treatment between naturally-occurring hormones (no regulation at all) and artificially administered hormones (a total ban). Here, the AB endorsed the EC's adoption of a zero-tolerance policy on hormone-treated beef by denying a comparison itself between these two situations in direct defiance of the conventional science which experts (scientists) represented in their opinions in this dispute. These scientists viewed that health risks from residual hormones in our body would be the same regardless of "differences in pathways taken or metabolites," i.e., whether endogenously present or consumed via foods. ${ }^{97}$ Nonetheless, the AB replaced this conventional science by its own version when it transcendentally declared that there exists a "fundamental difference" between these two situations. ${ }^{98}$ It further criticized any

${ }^{93}$ Panel Report, European Communities-Measures Concerning Meat and Meat Products (Hormones), ๆ8.171, WT/DS26/R (Aug. 18, 1997).

94 "[A]ll scientific experts advising the Panel have concluded that residues of the three natural hormones present endogenously in meat and other foods or administered for therapeutic or zootechnical purposes are qualitatively the same as the residues of these hormones administered for growth promotion and that if any differences between these hormones could exist (e.g., differences in pathways taken or metabolites), these differences would in any event not have consequences for the potential adverse effects of these hormones." Id. at 98.187 (emphasis added).

${ }^{95} \mathrm{Id}$. at $\mathbf{9 8 . 5 5 .}$

${ }^{96} \mathrm{Id}$. at $\mathbf{9} 8.197$.

${ }^{97} \mathrm{Id}$. at $₫ 8.187$.

98 Appellate Body Report, European Communities-Measures Concerning Meat and Meat Products (Hormones), ๆ221, WT/DS26/AB/R (Jan. 16, 1998). 
attempt to compare them as "absurdity." "Therefore, the AB sided with the EC which also argued that such fundamental difference in these two situations justified fundamentally different treatments (no intervention and a total ban) in them.

The AB's new science is quite reminiscent of the Kuhnian paradigm shift in that the $A B$ changed the way which one should read and interpret the science as to hormones in food. ${ }^{100}$ It rejected the conventional science, i.e., laboratory science, over a common sense-based science which may befit the "real world where people live and work and die." In doing so, the $\mathrm{AB}$ effectively created a new presumption in favor of the EC's zerotolerance policy which was embodied in a total ban on hormone-treated beef. Suddenly, the hitherto defensive EC's position seemed to turn offensive. Now, the United States should bear the burden of proving that the EC's ban was still arbitrary and unjustifiable. Alas, however, the presumption is irrebuttable since the AB opined that the EC's regulatory choice was basically incommensurable and sui generis. Simply, there exist no referential points against which one might evaluate its scientific justification. This might be bad news to the United States in this adversarial game.

\section{B. Scientific Uncertainty, Hercules and Phronesis}

The Hormones case is not an isolated, idiosyncratic anecdote: it certainly shares the same milieu with a modern ethos of social hygiene and welfare state fueled by highly emotionalized and thus politicized scandals on mad cow diseases and Frankenfoods. ${ }^{101}$ Amid scientific uncertainty characterized by both too little and too much information, the same problem often generates totally different responses: some are risk-friendly as in the United States; others are risk-averse as in Europe. As Richard Gaskin observed, "it is now more fashionable to investigate the political and cultural frameworks surrounding scientific expertise." 102 These diametrically opposite regulatory philosophies in different jurisdictions naturally entail highly dogmatic use of the BOP. In asserting one's own position, one tends to employ polemic strategies to highlight the opponent's inability to disprove her default premise (presumption). ${ }^{103}$ Emanuel Kant earlier coined this tendency as the "polemical employment of pure reason." Kant observed that:

Here the contention is not that [one's] own assertions may not, perhaps, be false, but only that no one can assert the opposite with apodeictic certainty, or even, indeed, with a greater degree of likelihood."104

\section{${ }^{99} \mathrm{Id}$.}

100 In this sense, Jeffrey Atik observed that the Kuhnian paradigm shift is a "process of interpretation, not of observation.” Jeffrey Atik, Science and International Regulatory Convergence, 17 Nw. J. INT'L L. \& BUS. 736, 751 (1996-97).

${ }^{101}$ Julie A. Moore, Frankenfood or Doubly Green Revolution: Europe vs. American on the GMO Debate, http://www.aaas.org/spp/rd/ch14.pdf (last visited February 28, 2007).

${ }^{102}$ GASKIN, supra note_, at 142.

${ }^{103} \mathrm{Id}$., at 212.

${ }^{104}$ IMMANUEl KANT, CRITIQUE OF PURE REASON 739-40 (1964). 
Obviously, such dogmatic confrontation between parties tends to result in a perpetual dispute armed with "arguments-from-ignorance, ${ }^{105}$ which the Court may want to end with its vested judicial authority. Here, the Court inevitably assumes the role of transcendental tribunal, which Ronald Dworkin dubbed Hercules, which always renders "right answers" in that it brings to the dispute finality "at the margins of scientific knowledge" upon which parties themselves can never agree. ${ }^{106}$ In other words, the dimension in which the Court bestows its judgment upon disputants is transcendental because such judgment may not be reduced to those empirical scientific facts which disputants themselves maneuver against each other: the decision is of law, its hermeneutics and values behind it.

Although the Court does embrace scientific facts which disputants adduce as evidence supporting their arguments, it never accepts them as they are. Instead, the Court assesses and interprets them in a way which sustains its own conclusion. Even expert opinions which the Court hears are not meant to replace the Court's own judgment. The Court is free to selectively adopt those professional views or even depart from them entirely. More fundamentally it is within the Court's discretion to decide when and whether to hear those opinions in the first place.

The Court's transcendental judicialization of science is amenable to a skeptical, or at least ambivalent, posture toward the authority of science echoed by Karl Popper and Thomas Kuhn. Popper was highly doubtful of modern science's capability to establish universal laws and thus understood science only as a process, rather than the product of investigation. ${ }^{107}$ In the Popperian perspective, one may prove that a certain scientific finding is wrong, but cannot prove that such finding is true in a definite, apodeictic sense. ${ }^{108}$ From this perspective, any scientific discovery only tentatively holds water until it is proven wrong in the future. ${ }^{109}$ In a similar vein, Kuhn conceptualized this inherent limited value and influence of modern science in his famed term, "paradigm." ${ }^{110} \mathrm{~A}$ paradigm of specific scientific disciplines ("normal science") created and exercised by a selective scientific community is subject to being shifted in a different socio-cultural setting. Once shifted, the old and new paradigms are incommensurable.

The $\mathrm{AB}$ in Hormones appears to subscribe to the Kuhnian perspective. To the $\mathrm{AB}$, an international standard would be a reification of normal science observed by a narrowly-defined epistemic community such as the Codex Alimentarius Commission.

\footnotetext{
${ }^{105}$ GASKIN, supra note , at 172-6.

${ }^{106} \mathrm{Id}$., at 213.

${ }^{107}$ See notably Karl Popper, The LOGIC OF SCIENTIFIC Discovery (1959); GASKIN, supra note_, at 152 .

${ }^{108}$ Atik, supra note_, at 750 (citing KarL R. POPPER, THE LOGIC OF SCIENTIFIC Discovery (1962)).

${ }^{109} \mathrm{Id}$.

${ }^{110}$ See notably Thomas S. Kuhn, The Structure of Scientific ReVolutions (2d ed. 1970); GASKIN, supra note_, at 152-53.
} 
This specific version of science may not be authoritative enough to preempt different paradigms which a regulating country may adopt in determining its own appropriate level of protection. Therefore, the $\mathrm{AB}$ refused to impose the $\mathrm{BOP}$ to a regulating party which has decided to depart from the international standard. ${ }^{111}$ Likewise, in deciding whether the regulating party has conducted risk assessment based on scientific justification, the $\mathrm{AB}$ did not prioritize a certain paradigm espoused by a certain group of scientists, such as a mainstream view, over a different paradigm, such as a minority view, because these two would be incommensurable.

The $A B$ even rejected a comparison of residual hormone levels in human body and food with those in beef treated with growth promoting hormones. The $A B$ reached this conclusion rather summarily, observing that any attempt to compare these two regulatory situations would lead to "absurdity." 112 This phronesis-driven paradigm rebuffs the normal science reincarnated in the Codex standard on the residual hormone levels, thereby rendering these two paradigms incomparable. To the $\mathrm{AB}$ as a reincarnation of Dworkian Hercules, political freedom based on reality and common sense should trump awkward laboratory science. This phronesis, not techne, should be a guiding principle under which the Court allocated an initial $\mathrm{BOP}$ as well as prescribe what to prove and whether to prove. Under this cognitive framework, it may be justified that a society reacts more seriously to any carcinogenic risks from environmental asbestos concentration (1 death per 100,000 or less) than to those from car accidents $(1,600$ deaths per 100,000), despite an enormous stochastic gap between these two situations. ${ }^{113}$

Here, the AB's position is akin to Edmund Husserl's criticism of modern science as a "mathematization of nature" totally detached from the "life-world" (Lebenswelt) ${ }^{114}$ From the AB's prioritization of common sense (wisdom) over laboratory science (knowledge), one might catch a glimpse of the tradition of critical philosophy of anti-scientism which accuses scientific positivism espoused by August Conte of a self-fulfilling prophesy fatally alienated from actual life-world and human interests. ${ }^{115}$ In this sense, the AB's rendition of science is close to the titular "trans-science" whose properties lie on a continuum between pure scientific facts and value (policy) judgment. ${ }^{116}$

${ }^{111}$ Appellate Body Report, European Communities-Measures Concerning Meat and Meat Products (Hormones), ๆ102, WT/DS26/AB/R (Jan. 16, 1998).

${ }^{112} \mathrm{Id}$. at $₫ 221$

113 Panel Report, European Communities-Measures Affecting Asbestos and Products Containing Asbestos, I3.54, WT/DS135/R (Sept. 18, 2000); B.T. Commins, Estimations of Risk from Environmental Asbestos in Non-Occupational Exposure to Mineral Fibres, IARC SCIENTIFIC PUBLICATION NO. 90, 476-483 (1989).

${ }^{114}$ Simon CRitchley, CONTINENTAl Philosophy: A Very SHORT Introduction 71 (2001).

${ }^{115} \mathrm{Id}$. at 112; See notably JÜRGEN HABERMAS, KNOWLEDGE AND HUMAN INTERESTS (1968).

116 See Alvin M. Weinberg, Science and Trans-Science, 10 MinerVA 209 (1972); Thomas O. McGarity, Substantive and Procedural Discretion in Administrative Resolution of Science Policy Questions: Regulating Carcinogens in EPA and OSHA, 67 GEO. L. J. 729, 732-47 (1979). Both articles are cited in Walker, supra note_, at 251 n.1.. 
Perhaps the $A B$ responded to the "democratic" concerns associated with regulatory decisions. Robert Howse locates a democratic value in the AB's SPS jurisprudence. Howse views that the $A B$ instilled the value of democratic rationality among citizens in the SPS interpretation by reserving a certain deliberative space where citizens' value judgments can effectively trump any mainstream science. ${ }^{117}$ To Howse, the AB's rejection of a widely accepted distinction between risk assessment (based on facts and science) and risk management (based on non-scientific, value-oriented judgments) might attest to the $A B$ 's fidelity to the democratic value in that deliberative room may be bigger in the absence of a strict dichotomy between science and value. After all, the AB's image of science does not originate from laboratories but from the "real world where people live and work and die." ${ }^{118}$ To the AB, science, at least for the purposes of SPS, should be based on practical wisdom (phronesis), rather than on technical knowledge (techne).

\section{Appraising the World Trade Court's Burden: A Critical Perspective}

\section{A. Diverging Oracles from Hercules: Incoherent Jurisprudence}

In the area of social regulation, in particular risk regulations such as SPS measures, the Court's interpretive posture discussed above, i.e., judicialization of science, has been a driving force behind the WTO jurisprudence. Unfortunately, however, the aforementioned Herculean "right answer" thesis, which has been embedded in the Court's prescriptive hermeneutics and thus applied to highly controversial scientific disputes, has created incoherent jurisprudence as it renders diverging findings over similar provisions or situations under the SPS Agreement and GATT Article XX. This jurisprudential incoherency can be found in three different yet still interrelated aspects: within the SPS Agreement, between the SPS Agreement and GATT Article XX, and finally between law and facts.

This incoherency is problematic since it costs the WTO jurisprudence its vital asset, i.e., predictability. In addition, as Ronald Allen poignantly observed, while consistency may not ensure correctness, incoherency tends to guarantee errors. ${ }^{119}$ After all, diverging oracles from Hercules might confuse its receivers and therefore become a disservice, not a contribution, to them.

${ }^{117}$ Robert Howse, Democracy, Science, and Free Trade: Risk Regulation on Trial at the World Trade Organization, 98 MiCH. L. REV. 2329, 2342-43 (2000).

${ }^{118}$ Id. at 2343-4; Appellate Body Report, European Communities-Measures Concerning Meat and Meat Products (Hormones), \187, WT/DS26/AB/R (Jan. 16, 1998).

${ }^{119}$ Ronald J. Allen, Burdens of Proof, Uncertainty, and Ambiguity in Modern Legal Discourse, 17 HARV. J. L. \& POL'Y 627, 644 (1994). 


\section{Incoherency within the SPS Agreement}

In Hormones, the $\mathrm{AB}$ was faithful to the principle of in dubio mitius. The $\mathrm{AB}$ basically characterized the health risks, i.e., carcinogenicity from beef hormones, as sui generis and incomparable to otherwise similar regulatory situations, such as health risks from endogenously occurring hormones. Hence, it found an unarbitrary and justifiable distinction between these two regulatory situations. The $\mathrm{AB}$ therefore accorded the $\mathrm{EU}$ a strong presumption in favour of its regulatory determination, which made it impossible for the complainant, the United States, to rebut. In the same context, the $A B$, quite contrary to how SPS text is structured, accorded the EC the right to depart from the relevant international standards (Codex standards) as well as the right to choose a zero-tolerance level of protection, disregarding the possibilities of any controlled use.

Nonetheless, the Court has often departed from this deferential, sovereigntypreserving hermeneutics in subsequent cases involving similar regulatory circumstances. In Salmon, the AB simply viewed the risks of diseases from ocean-caught salmon as comparable to those from herring used as bait and live ornamental finfish, while Australia vehemently argued for unique regulatory challenges that foreign salmon generated in terms of potential diseases. Australia noted that "salmon represented the only finfish on which a species-specific level of protection had been established"120 and that "risks associated with other aquatic animals could not be compared in the absence of a risk analysis." 121

Here, Australia's regulatory posture seems quite similar to that of the EU in Hormones, i.e., risk-averse, zero-tolerance level of protection in the absence of positive scientific evidence corroborating the hormoned beef's safety. In other words, Australia would not need to adduce apodeicdic evidence proving that its ban on ocean-caught salmon is justifiable. Yet, the $\mathrm{AB}$, in upholding the panel's view, opined that a common risk of contracting only one common disease is sufficient enough to make two regulatory situations comparable. ${ }^{122}$ According to the AB's approach, any two regulatory situations may still be comparable as long as they share at least one common element (e.g., disease) even though one is subject to additional risks (e.g., multiple, unknown diseases) than the other. Therefore, the $\mathrm{AB}$ substituted its own risk-friendly regulatory determination for Australia's more cautious one.

However, why should these two regulatory situations in Salmon, i.e., risks from ocean-caught salmon and those from herring used as bait and live ornamental finfish, be treated as "comparable," while two other regulatory situations in Hormones, i.e., risks from naturally occurring hormones and those from artificially administered hormones, were

${ }^{120}$ Panel Report, Australia-Measures Affecting the Importation of Salmon, I 4.187, WS/DS18/R (June 12, 1998)

${ }^{121} \mathrm{Id}$. at $\boldsymbol{\top} 4.189$.

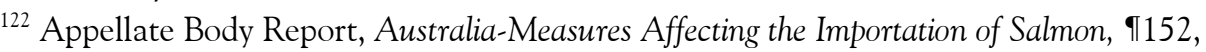
WT/DS18/AB/R (Oct. 20, 1998). 
treated as "incomparable" despite that health risks from residual hormones in our body would be the same regardless of "differences in pathways taken or metabolites"? ${ }^{123}$ The $\mathrm{AB}$ rendered no explanation at all on this serious jurisprudential incoherence.

Once the $A B$ framed these two regulatory situations, i.e., regulating the importation of ocean-caught salmon, and that of herring used as baits and live ornamental finfish, comparable, the rest of the analysis under Article 5.5 seems to be rather automatic. First, the presence of sheer difference in regulatory treatment between the two situations, i.e., prohibiting importation and permitting importation, led the $A B$ to generate a nearly irrebuttable presumption of "arbitrary and unjustifiable" discrimination in favour of the complainant as the complainant only had to demonstrate the existence of such difference. It was the defendant (regulating state) which should rebut the complainant's argument by proving in turn that its regulation would be still unarbitrary and justifiable, which seemed to be quite daunting.

Second, such arbitrariness and unjustifiability, once found, determines the onus of burden as to the rest elements of Article 5.5 to the detriment of defendants. Under the euphemistic labels of "warning signals," the AB simply derived additional presumptions on the existence of "discrimination or a disguised restriction on international trade" which are also detrimental to the defendant, from the original presumption of arbitrariness and unjustifiability. ${ }^{124}$ Under these circumstances, the defendant could hardly rebut such strong presumptions.

This second-guessing on risk determination by the Court, which is certainly at variance with Hormones, culminates with its selective imposition of proof burden on a specific group of products in question. In Japan-Apple, a complaining party (the United States), in proving that Japan's sanitary measures against the United States' apples were maintained without sufficient scientific evidence, presented arguments and evidence concerning only "mature, symptomless" apples. ${ }^{125}$ Japan argued that the United States should also establish a prima facie case that "infected" apples would pose no risk as mature and symptomless apples would. ${ }^{126}$ However, both the panel and the AB ruled that it was Japan which should come up with any scientific evidence for such risk that infected apples would cause. ${ }^{127}$ The AB held that:

[T]he Appellate Body's statement in EC - Hormones does not imply that the complaining party is responsible for providing proof of all facts raised in relation to the issue of determining whether a measure is consistent with a given provision of

${ }^{123}$ Panel Report, European Communities-Measures Concerning Meat and Meat Products (Hormones), ๆ1887, WS/DS26/R (Aug. 18, 1997).

${ }^{124}$ Appellate Body Report, Australia-Measures Affecting the Importation of Salmon, ๆף161-163, WT/DS18/AB/R (Oct. 20, 1998).

125 Appellate Body Report, Japan-Measures Affecting the Importation of Apples, \$149, WS/DS245/AB/R (Nov. 26, 2003).

${ }^{126} \mathrm{Id}$.

${ }^{127} \mathrm{Id}$. at ๆฯ149, 154. 
a covered agreement. In other words, although the complaining party bears the burden of proving its case, the responding party must prove the case it seeks to make in response. ${ }^{128}$

Critically, this innocuous-sounding construction by the $\mathrm{AB}$ on the $\mathrm{BOP}$ in fact betrays its hidden hermeneutical agenda, i.e., judicialization of science. The AB rationalized such mitigated BOP borne to the United States, i.e., the burden of making a prima facie case only with respect to "mature, symptomless" apples, on the ground that other apples, such as immature, infected apples, pose only a "small" or "debatable" risk which derives from human, technical errors and illegal actions. ${ }^{129}$ Here, the AB played the role of scientist, rather than judge. As a result, the AB bestowed on the United States a presumption of safety with respect to all apples it exports to Japan by allowing it to limit its proof burden to those apples in a normal situation. However, a sanitary regulation does not necessarily presuppose such normal situations. On the contrary, a sanitary regulation should take into account those errors and illegal actions which might actually happen. Basing its level of protection on such an optimistic scenario can hardly be imagined in any regulatory jurisdictions. In this context, the AB's posture disregarding such risks, albeit small, is an unbearable risk-taking, which is a stark contrast with Hormones advocating a zero-tolerance approach to health risks. ${ }^{130}$

All in all, these substantive rulings on specific risks which result in a risk-taking approach in Salmon and Japan-Apples depart blatantly from the deferential approach that the $\mathrm{AB}$ had taken in comparable cases, such as Hormones, in which the $\mathrm{AB}$ endorsed a "zero-tolerance" regulatory policy. Accordingly, the AB's position deprives regulating states, such as Australia and Japan, of a presumption of legality (a right to regulate) and requires a heavy burden of adducing positive scientific evidence proving that peculiar risks might occur in the imported products in questions, such as ocean-caught Pacific salmon and apples from the United States.

\section{Incoherency between GATT and the SPS Agreement}

In addition to the SPS Agreement, Article XX (General Exceptions) of GATT also provides a justification mechanism with which a regulating country can prove that their health or other social regulations are necessary to achieve legitimate policy objectives. As within the SPS Agreement, one can witness yet another jurisprudential incoherency between the SPS Agreement and GATT over similar regulatory situations. The Court's own substantive evaluation of various societal risks in deciding whether a certain measure was really necessary to achieve a putative regulatory goal under GATT

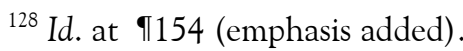

${ }^{129} \mathrm{Id}$. at $₫ 160$.

${ }^{130}$ In its third party argument, the EC viewed that "the United States should have established a prima facie case showing that Japan's measure was not necessary or was disproportionate, including with respect to the importation of infected fruit.” Id. at $₫ 109$ (emphasis in original). 
Article XX tends to complicate a holistic understanding of its jurisprudence related to the similar regulatory situation subject to the SPS Agreement which bestows a right to regulate.

At first blush, the Court's interpretations on GATT and SPS seem to converge. In determining whether a French ban over Canadian asbestos products was necessary to protect human health under GATT Article XX (b), the Asbestos court issued the SPSline of statement, i.e., "it is undisputed that WTO Members have the right to determine the level of protection of health that they consider appropriate in a given situation." 131 Then, the AB upheld the zero-tolerance policy over asbestos adopted by France, noting that "controlled use" would not be an alternative since it would not guarantee a zero risk that France had pursued. ${ }^{132}$ Undoubtedly, this strong presumption in favor of France's regulatory autonomy tends to relieve France of its otherwise heavy burden of proving that its ban was necessary to protect human health as an exception, not as a right, under GATT Article XX (b).

However, the pendulum of the Court's substantive interpretation on risks and regulations swing to the opposite direction in other similar situations under GATT Article XX. In Korean Beef, the United States challenged the Korean "dual retail system" under which foreign beef should be sold separately from domestic beef (Hanwoo) to prevent deceptive practices by retailers to misrepresent cheaper imported beef as more expensive Hanwoo. This rather drastic measure, which is in fact a zero-risk approach to these fraudulent practices, could be deemed necessary considering not only high commercial values on Hanwoo but also certain socio-cultural attachments to this indigenous beef within the unique context of Korean society. Even the panel acknowledged that the system was introduced at a time when these frauds were widespread in the beef sector and that it "does appear to reduce the opportunities and thus the temptations for butchers to misrepresent [less expensive] foreign beef for [more expensive] domestic beef." 133

If a reasonable person applies the Hormone and Asbestos case law to this situation, she would find few difficulties in finding that the dual retail system was necessary to prevent frauds. However, in a diametrically opposite posture from Hormones and Asbestos, the Court in Korean Beef second-guessed the Korean government's regulatory judgment

131 Appellate Body Report, European Communities-Measures Affecting Asbestos and Products Containing Asbestos, ๆ168, WT/DS135/AB/R (Mar. 12, 2001).

132 "In our view, France could not reasonably be expected to employ any alternative measure if that measure would involve a continuation of the very risk that the Decree seeks to "halt". Such an alternative measure would, in effect, prevent France from achieving its chosen level of health protection.... Given these factual findings by the Panel, we believe that "controlled use" would not allow France to achieve its chosen level of health protection by halting the spread of asbestos-related health risks. "Controlled use" would, thus, not be an alternative measure that would achieve the end sought by France." Id. at $\$ 174$.

133 Panel Report, Korea- Measures Affecting Imports of Fresh, Chilled and Frozen Beef, I658, WS/DS169/R (July 31, 2000). 
through the creation of a quite intrusive doctrine, the "weighing and balancing" test. The $A B$ viewed that:

In sum, determination of whether a measure, which is not "indispensable", may nevertheless be "necessary" within the contemplation of Article $\mathrm{XX}(\mathrm{d})$, involves in every case a process of weighing and balancing a series of factors which prominently include the contribution made by the compliance measure to the enforcement of the law or regulation at issue, the importance of the common interests or values protected by that law or regulation, and the accompanying impact of the law or regulation on imports or exports. ${ }^{134}$

This doctrine strips regulating members of their regulatory autonomy in that the Court, not the regulating country, would judge over all the details related to a given measure in question. In effect, the doctrine usurps from the regulating country a critical presumption of in dubio mitius and thus gravely increases its proof burden in litigation. Obviously, this omniscient attitude of the Court is yet another manifestation of its Herculean image. The Court appears to believe that it, not the regulating country, is capable of delivering right answers on critical regulatory questions, such as "the extent to which the measure contributes to the realization of the end pursued, the securing of compliance with the law or regulation at issue." 135

Saddled with this commandeering interpretive posture, Hercules in Korean Beef de facto overrode Hormones without rendering any plausible reasons. First, in Hormones, the $\mathrm{AB}$ refused to equate a regulatory situation over naturally-occurring hormones with that over artificially-treated hormones, despite the conflicting scientific evidence. However, in Korean Beef, the AB trivialized the uniqueness of the Korean regulatory challenge over domestic beef by comparing Hanwoo with other more mundane foods, such as pork and seafood. ${ }^{136}$ Tellingly, the very fact that Korea had not suffered any major scandals on the misrepresentation of foreign pork or foreign seafood as domestic counterparts testifies to the incomparability between these two regulatory situations.

Second, by implementing a dual retail system, the Korean government took a very conservative approach toward this problem, which is analogous to a zero-tolerance policy in Hormones. The AB should have respected this high level of protection in the beef sector by the Korean government, as it accepted the EC's total ban as legitimate and thus rejected the complainant's arguments on the "controlled use." Yet, in Korean Beef, the AB replaced the Korean regulatory determination by its own right answer and ruled that Korea could have used softer measures, which are tantamount to the controlled use in

\footnotetext{
${ }^{134}$ Appellate Body Report, Korea- Measures Affecting Imports of Fresh, Chilled and Frozen Beef, $₫ 164$, WS/DS169/AB/R (Dec. 11, 2000) (emphasis added).

${ }^{135} \mathrm{Id}$. at $₫ 163$.

${ }^{136} \mathrm{Id}$. at $₫ 168$.
} 
Hormones, such as fines, record-keeping and policing. ${ }^{137}$ Here, the AB simply ignored a fundamental fact that the dual retail system had to be introduced only because these conventional enforcement measures did not work.

Critically, this Herculean second-guessing shaped the contour of the Court's decision on the BOP. First, the AB, siding with the panel, placed a high proof burden on Korea under which Korea should prove that "no alternative measure consistent with the WTO Agreement is reasonably available at present. ${ }^{1138}$ Then, the AB ruled that those conventional enforcement measures applied to the same kind of illegal behaviors were reasonably expected. ${ }^{139}$ Therefore, the $\mathrm{AB}$ simply dismissed the Korean zero-tolerance policy as unpersuasive, i.e., failing to discharge the abovementioned proof burden, ${ }^{140}$ instead of according Korea a margin of appreciation on its own regulatory situation, as the $\mathrm{AB}$ certainly did in Hormones. The AB's own regulatory solution, which made the dual retail system look unreasonable, sounds almost admonishing. The $A B$ viewed that:

Violations of laws and regulations like the Korean Unfair Competition Act can be expected to be routinely investigated and detected through selective, but well-targeted, controls of potential wrongdoers. The control of records will assist in selecting the shops to which the police could pay particular attention. ${ }^{141}$

It seems puzzling why the $\mathrm{AB}$ did not rule in the same way over this kind of regulatory alternative (controlled use) in Hormones and Asbestos. In Asbestos, Canada demonstrated that technological innovations created various regulatory alternatives to a total asbestos ban adopted by France, and that a number of countries were in fact implementing these alternatives. ${ }^{142}$ In its third-party submission, Zimbabwe also pointed out some plausible alternatives to the ban, including the disclosure requirement assisting consumers to make informed decisions on asbestos products as well as the certification system for those who treat asbestos. ${ }^{143}$ Nonetheless, the $\mathrm{AB}$ ruled that:

[I]t is undisputed that WTO Members have the right to determine the level of protection of health that they consider appropriate in a given situation. France has determined, and the Panel accepted, that the chosen level of health protection by France is a "halt" to the spread of asbestosrelated health risks. ${ }^{144}$

${ }^{137} \mathrm{Id}$. at $\mathbf{\Upsilon 1 8 0}$.

${ }^{138} \mathrm{Id}$. at $₫ 167$ (emphasis added).

${ }^{139} \mathrm{Id}$. at $\$ 172$ (emphasis added).

${ }^{140} \mathrm{Id}$. at $₫ 181$.

${ }^{141} \mathrm{Id}$.

${ }^{142}$ Panel Report, European Communities-Measures Affecting Asbestos and Products Containing Asbestos , \3.55, WS/DS135/R (Sept. 18, 2000).

${ }^{143} \mathrm{Id}$. at $\mathbf{9 \top 4} 4.97-98$.

144 Appellate Body Report, European Communities-Measures Affecting Asbestos and Products Containing Asbestos, \168, WT/DS135/AB/R (Mar. 12, 2001). 
In our view, France could not reasonably be expected to employ any alternative measure if that measure would involve a continuation of the very risk that the Decree seeks to "halt". Such an alternative measure would, in effect, prevent France from achieving its chosen level of health protection. $^{145}$

This utter incoherence between Hormones/Asbestos (SPS) and Korean Beef (GATT) is quite problematic in that it tends to send a confusing signal to the audience in the global trading community and thus discourages a holistic understanding of the Court's jurisprudence.

\section{Inconsistency between Law and Facts}

The Court has addressed the BOP question, such as whether to prove or what to prove, in a selective, and therefore inconsistent, manner between a matter of law and that of fact. Sometimes, the Court sidesteps the BOP question by constructing certain controversial issues as a matter of fact and thus deferring the question to the lower tribunal (panel)'s interpretation. Some other times, however, the Court itself engages in the BOP question by constructing those issues of controversy as a matter of law.

In Dominican Cigarette, the tax code of the Dominican Republic required that stamps be affixed on all cigarette packets in its territory. Although the tax stamp requirement applied to both domestic and foreign cigarettes, foreign cigarette producers decried the requirement as discriminatory since stamps had to be affixed on the imported cigarette packets in the Dominican warehouses in the presence of Dominican tax inspectors, instead of being affixed in the exporting countries beforehand. ${ }^{146}$

The Dominican Republic justified the tax stamp requirement under GATT Article XX (d), claiming that it was "necessary" to prevent tax evasion and cigarette smuggling. ${ }^{147}$ In the same line with Hormones and Asbestos, the Dominican Republic argued that it has "no reasonable alternatives" to achieve its desired level of enforcement, which it has the right to determine. ${ }^{148}$ Both the case law and international practices on this subject seem to support the Dominican position. The panel in Argentina - Hides and Leather certainly recognized that prevention techniques, such as tax stamps, could address

${ }^{145} \mathrm{Id}$. at $\uparrow 174$.

${ }^{146}$ Panel Report, Dominican Republic-Measures Affecting the Import and Sale of Cigarettes, $\mathbf{9 4 . 3 ,}$ WT/DS302/R (Nov. 26, 2004).

${ }^{147} \mathrm{Id}$. at $\$ 4.89$.

${ }^{148} \mathrm{Id}$. at 94.93 . 
tax evasion. ${ }^{149}$ The International Conference on Illicit Tobacco Trade (ICITT) has also identified tax stamps as a legitimate tool to deter distribution of illegal imports. ${ }^{150}$

However, the panel viewed that a reasonable alternative, such as "providing secure tax stamps to foreign exporters and affixing the stamps abroad, possibly under the supervision of a reputable company that would conduct pre-shipment inspection and certification," was available, and thus held that the Dominican Republic had failed to establish that the tax stamp requirement is justified under GATT Article XX(d). ${ }^{151}$ The Dominican Republic appealed this ruling, highlighting that cigarette producers "actively collaborate" to smuggle cigarettes and that alcoholic beverages are vastly smuggled when allowing the affixation of tax stamps abroad. ${ }^{152}$

The AB upheld the panel's ruling, yet did so in a rather astounding logic. The AB blindly endorsed the panel's second-guessing of the Dominican regulatory situation, which departed from the previous jurisprudence in Hormones and Asbestos. The AB simply categorized the panel's view that the tax stamp requirement was "of limited effectiveness" as "findings of fact" and deferred this issue to the panel under DSU Article 11. ${ }^{153}$ In other words, the AB unconditionally accepted the panel's findings on such issues as "limited effectiveness of the tax stamp requirement in preventing forgery, smuggling and tax evasion; greater effectiveness and efficiency of measures such as security features incorporated into the tax stamps or police controls." 154

However, the panel's findings concern more of the standard of review or deference, rather than of factual findings. Although these findings do involve certain facts, a more fundamental question is whether the panel, not the Dominican Republic itself, should render a definite prescription on this regulatory problem. In Hormones and Asbestos, the $\mathrm{AB}$ upheld the right to regulate as well as the principle of in dubio mitius, thereby never second-guessing the zero-tolerance policy. While this deferential interpretation, or the liberal standard of proof, certainly involves an issue of law, the AB in this case labeled it as an issue of fact and thus escaped its burden.

Under the AB's logic, it should have also accepted the panel's findings in Gambling as factual findings. In Gambling, the panel concluded that the U.S.' ban on cross-border gambling was not a necessary measure since the U.S. could have pursued a reasonably available alternative, i.e., "engaging in consultations with Antigua, with a view to arriving at a negotiated settlement that achieves the same objectives as the challenged

${ }^{149}$ Panel Report, Argentina-Measures Affecting the Export of Bovine Hides and the Import of Finished Leather, \11.305, WT/DS155/R (Dec. 19, 2000).

${ }^{150}$ Panel Report, Dominican Republic-Import and Sale of Cigarettes, ๆ4.90, WT/DS302/R (Nov. 26, 2004).

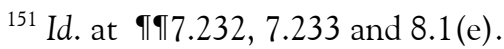

${ }_{152}$ Appellate Body Report, Dominican Republic-Measures Affecting the Import and Sale of Cigarettes, \12, WT/DS155/AB/R (Aug. 31, 2001).

${ }^{153} \mathrm{Id}$. at 971 .

${ }^{154} \mathrm{Id}$. 
United States' measures." ${ }^{155}$ Yet, the $\mathrm{AB}$ rejected the panel's finding as flawed in that the panel's solution was not a reasonable alternative because "consultations are by definition a process, the results of which are uncertain and therefore not capable of comparison with the measures at issue in this case." 156

The incoherency between Dominican Cigarette and Gambling is prominent. The $\mathrm{AB}$ characterized the panel's "necessity" analysis under GATT Article XX as a matter of fact in the former case, while it constructed the same analysis as a matter of law in the latter case. Therefore, in the former case the panel's conclusion on whether (and what) to prove was upheld, while in the latter case the same conclusion was rejected.

In sum, if the $A B$ agrees with the panel's findings on critical issues, the $A B$ will elect not to intervene in the panel's findings on the ground that "the Panel's consideration and weighing of the evidence. . . relates to its assessment of the facts and, therefore, falls outside the scope of appellate review under Article 17.6 of the DSU." ${ }^{157}$ However, if the $A B$ disagrees with the panel's interpretation even on facts, the $A B$ will interfere with it by converting these originally factual issues into legal ones. This incoherent exercise of the Court's hermeneutical burden tends to undermine the credibility of WTO jurisprudence in general.

\section{B. Finality over Legitimacy: Legitimacy Crisis}

\section{Judicialization as Finality}

In addition to creating jurisprudential incoherency and its consequent confusion, the Court's judicialization of science and/or regulatory second-guessing through the BOP risks undermining the Court's legitimacy as a fair arbiter. Judicialization means finality since the Court's final ruling, once adopted, becomes the law in a given dispute: the case is closed for all. The Court might want to justify this finality through science or any other form of rationality. To the Court, science is a universal language through which the Court could authoritatively utter an ultimate substantive decision. As Hercules, the Court would always be capable of rendering a right answer for each dispute.

However, any specific version of science or other form of rationality which the Court picks for its own use may be just one out of many paradigms or perspectives. ${ }^{158}$

${ }^{155}$ Appellate Body Report, United States-Measures Affecting the Cross-Border Supply of Gambling, \317, WT/DS285/AB/R (Apr. 7, 2005).

${ }^{156} \mathrm{Id}$.

${ }^{157}$ Appellate Body Report, Australia-Measures Affecting the Importation of Salmon, $\mathbb{1 2 6 1}$, WT/DS18/AB/R (Oct. 20, 1998).

158 "Scientific knowledge, one finds, is hardly universal. What is true and certain within one scientific community constitutes baseless conjecture in another. Science is also intrinsically historical; it is science-of-the-moment." Atik, supra note _, at 738. 
Critically, this peculiar way of understanding and interpreting science leads the Court to disregard certain responses from parties and attach importance to one kind of response over others. ${ }^{159}$ It is at this juncture that the Court's judicialization of science becomes "political," not scientific (objective). Under these circumstances, the Court's exercise of its hermeneutical burden over the BOP tends to erode its legitimacy by inviting more, not less, politics from the parties concerned.

Since the Court is not a political organ, such politicization would not be tolerated at least by a losing party which might resent the fact that it has lost its case due to political, not scientific (objective), reasons. If the losing party is an importer (regulating country), it would feel deprived of its regulatory autonomy, and even sovereignty. If the losing party is an exporter, it would feel frustrated over its stymied market access. Either such regulatory failure (under-regulation) or trade failure (over-regulation) would generate resentment of the losing party towards the Court, thereby eroding the Court's compliance pull, i.e., legitimacy. ${ }^{160}$

\section{Over-Regulative Finality: Science under Politics}

The Court's judicialization of science, and subsequently politicization of science, tends to make the Court more comfortable in departing from conventional scientific positions represented by widely accepted international standards and practices. In doing so, the Court not only blends science and politics but also marginalizes conventional science for the sake of politics.

At first glance, faced with tons of documents from both parties which only advocate their own versions (paradigms) of science as well as lengthy expert opinions, the Court's task seems to be that of a "Science Court" which determines "both the meaning and the merits of the risk assessment documents" as well as "the truth of various scientific propositions." ${ }^{161}$ It might purport to deliver a scientifically correct, and thus legitimate, answer. ${ }^{162}$

However, a WTO version of Science Court is fatally prone to politically motivated over-regulation and the consequent restraint of trade not only because WTO panelists and $\mathrm{AB}$ members are non-experts in these scientific matters but also because science can only be judicialized in a transcendental, which is basically political, fashion. ${ }^{163}$

${ }^{159}$ Atik, supra note , at 736-37.

${ }^{160}$ See Thomas M. Franck, The Power of Legitimacy among Nations 49 (1990).

${ }^{161}$ Walker, supra note _, at 301-2.

${ }^{162} \mathrm{Cf}$. Gaskin, supra note, at 163; Walker, supra note_, at 255 (arguing that the WTO should not become a "global mega-regulator" which would resolve scientific disputes involving carcinogenicity or acceptable levels of risks).

${ }^{163}$ See Theofanis Christoforou, Genetically Modified Organisms: Colloquium Article Settlement of Science-Based Trade Disputes in the WTO: A Critical Review of the Developing Case Law in the Face of Scientific Uncertainty, 8 N.Y.U. ENVTL. L.J. 622, 646 (2000) (criticizing that the current WTO dispute settlement 
For example, the $\mathrm{AB}$ in Hormones reversed the panel's ruling that a regulating party (EC), when its measure, i.e. a total ban, departed from the Codex standard on the residual hormone levels, should bear the burden of proving that the ban was nonetheless scientifically justified. The AB, driven by a politically charged assumption of members' regulatory prerogative, ruled that it is the complaining party (United States) which should prove that the ban was not scientifically justified. In doing so, the AB downgraded the significance of SPS-endorsed international standards, such as the Codex standard, despite the Agreement being seriously committed to those standards as a vehicle for harmonization. ${ }^{164}$

However, international standards, at least those that are explicitly recognized in the SPS Agreement, such as the Codex standard, are a reification of WTO Members' sovereignty-checking commitments to achieve a communal goal of harmonization. The $A B$ 's reversal of the BOP risks undoing these initial commitments and sending a false signal that a regulating country is free to disregard international standards whenever it finds them inconvenient. ${ }^{165}$ As a result, the AB's BOP hermeneutics on international standards may result in the serious underuse of these standards, thereby undermining their legitimacy. Moreover, members' indifference and lack of inputs to international standards would also deter these standards from being further developed and improved, which is evidently inconsistent with what the SPS Agreement envisions. ${ }^{166}$

Furthermore, in Hormones, the AB dismissed a legitimate distinction between risk assessment (science) and risk management (politics), which has widely been accepted in scientists' circles, ${ }^{167}$ purely on a narrow textual ground. ${ }^{168}$ As a result, the AB shrunk an

practice "leaves too much discretion to non-expert, non-specialized panellists to judge issues of tremendous scientific complexity"). See also David A. Wirth, The Role of Science in the Uruguay Round and NAFTA Tra de Disciples, 27 CORNELL INT'L L.J. 817, 844 (1994) (hereinafter Wirth, Role of Science) (observing that the idea of science court is impractical because science is not justiciable in an adversarial setting even if all the judges are scientists).

164 "To harmonize sanitary and phytosanitary measures on as wide a basis as possible, Members shall base their sanitary or phytosanitary measures on international standards, guidelines or recommendations, where they exist. .." SPS, supra note,, art. 3.1 (emphasis added). See Grando, supra note_, at 622-23, 632 (observing that the Hormone panel characterized SPS art. 3.3 as an exception to art. 3.1 based on the text ("except as otherwise provided for in this Agreement, and in particular in paragraph 3")).

${ }^{165}$ See Horn \& Weiler, supra note_, at 263; Joshua Meltzer, State Sovereignty and the Legitimacy of the WTO, 26 U. PA. J. INT'L ECON. L. 693, 721 (2005).

166 "Members shall play a full part, within the limits of their resources, in the relevant international organizations and their subsidiary bodies, in particular the Codex Alimentarius Commission, the International Office of Epizootics, and the international and regional organizations operating within the framework of the International Plant Protection Convention, to promote within these organizations the development and periodic review of standards, guidelines and recommendations with respect to all aspects of sanitary and phytosanitary measures." SPS, supra note_, art. 3.4 (emphasis added).

${ }^{167}$ See e.g., Food and Agricultural Organization (FAO) E World Health Organization (WHO), RISK MANAGEMENT AND FOOD SAFETY (1997).

${ }^{168}$ Appellate Body Report, European Communities-Measures Concerning Meat and Meat Products (Hormones), ๆ176, WT/DS26/AB/R (Jan. 16, 1998). 
independent space for conventional science under the SPS. The conventional science in this case was at odds with the ban as it dismissed the necessity of regulatory differentiation between naturally occurring hormones and artificially injected hormones despite their different pathways. ${ }^{169}$ The Hormone panel attempted to preserve the integrity of this critical scientific finding by distinguishing risk assessment (an "examination of data and studies") ${ }^{170}$ from risk management (a "policy exercise involving social value judgments made by political bodies"). ${ }^{171}$ Yet, the AB dramatically undermined the rigor of a risk assessment requirement, and thus science itself, by electing a very loose construction of risk assessment permitting the consideration of non-empirical, nonexperimental factors, which could encompass even non-scientific considerations, such as fears and human biases. ${ }^{172}$

Critically, widely accepted scientific practices, which are the outcome of hitherto scientific deliberation and discourse, should not be discarded lightly. The AB's rather dogmatic stance like the one in Hormones may suffocate further discourse, and be abused to cater to pseudo-science and/or protectionism. Even politicians should heed what scientists have found: politicians should not manipulate science in a way which serves their political needs.

If we maintain a distinction between risk assessment (science) and risk management (politics), we may at least locate a logical sequence between these two stages. In other words, risk assessment should come before risk management, not vice versa. Without a scientific investigation in the first place, the determination of an appropriate level of protection could not be obtained. Yet, in Hormones the AB ignored this sequence and in effect mingled risk assessment and risk management.

The AB did recognize that the EC failed to comply with Article 5.1 of the SPS Agreement since the EC conducted no assessment on risk caused by any abusive use of hormones and the administrative difficulties in control of the hormones for growth promotion purposes. ${ }^{173}$ The EC therefore failed to provide any scientific assessment on the administrative risk (controlled use) vis-à-vis the zero-tolerance policy. This failure should have generated a presumption that the EC's determination of its level of protection would not be appropriate. After all, how could the EC confidently choose the zero-tolerance level of protection, which would deny the possibilities of controlled use or administration

${ }^{169}$ Panel Report, European Communities-Measures Concerning Meat and Meat Products (Hormones), I 8.187, WT/DS26/R (Aug. 18, 1997).

${ }^{170} \mathrm{Id}$., ๆ $8.107,8.110$, WT/DS26/R (Aug. 18, 1997).

${ }^{171} \mathrm{Id}$. at 98.94 . But see Wirth, The Role of Science, supra note _, at 833 n.63 (documenting oppositions to this bifurcation).

172 Appellate Body Report, European Communities-Measures Concerning Meat and Meat Products (Hormones), ๆ187, WT/DS26/AB/R (Jan. 16, 1998) ("the actual potential for adverse effects on human health in the real world where people live and work and die"); Quick \& Blüthner, supra note,, at 616-17.

${ }^{173}$ Appellate Body Report, European Communities-Measures Concerning Meat and Meat Products (Hormones), ๆ207, WT/DS26/AB/R (Jan. 16, 1998). 
with good practice, without any scientific investigation on such an exorbitant option in the first place?

Therefore, under the AB's approach, the EC might ex post justify its predetermined strict regulatory position, shaped purely by political considerations, by locating, or even creating, favorable scientific studies. This sorry state of science under politics tends to advocate over-regulation at the expense of legitimate trade interests.

\section{Under-Regulative Finality: Regulatory Autonomy Lost}

The Court's Herculean hermeneutics over the BOP also tends to "second-guess" the regulating countries' legitimate policies. This is yet another judicialization of science in that the Court itself assesses all the risks and effectiveness of possible policy options through its own reasoning to deliver a substantive finality to a given dispute. Such finality may be labeled as political in that the Court's own reasoning may not always be shared by parties, in particular the losing party. The Court's second-guessing under GATT Article $\mathrm{XX}$ is conducted via the titular "weighing and balancing test" invented in Korean Beef. Under the test, the AB launched a highly intrusive judicial review in which it assessed both the means and ends of a domestic regulation in question. ${ }^{174}$

As discussed above, ${ }^{175}$ this test represents a serious incoherency in the Court's hermeneutics as it blatantly departs from its in dubio mitius standard established in Hormones. The basic assumption of the test is flawed since it presupposes Hercules who would know better than local regulators all the necessary details, such as the actual level of protection or what would have been necessary to achieve a certain legitimate policy objective in a given situation. Under the test, it would be very difficult for a defending (regulating) party to discharge its burden of proving that its measure was necessary to achieve its own level of protection before a seemingly omniscient, and commandeering, Court.

Another concern related to the weighing and balancing test centres on the NorthSouth tension. In most cases, developing countries' regulatory challenges as well as their regulatory solutions are unique and hard to generalize. Options available to developed countries may not be feasible to them mainly due to the lack of resources and capacity. If these circumstances are not fully taken into account under the weighing and balancing

174 "In sum, determination of whether a measure, which is not "indispensable," may nevertheless be "necessary" within the contemplation of Article XX (d), involves in every case a process of weighing and balancing a series of factors which prominently include the contribution made by the compliance measure to the enforcement of the law or regulation at issue, the importance of the common interests or values protected by that law or regulation, and the accompanying impact of the law or regulation on imports or exports." Appellate Body Report, Korea- Measures Affecting Imports of Fresh, Chilled and Frozen Beef, \164, WS/DS169/AB/R (Dec. 11, 2000) (emphasis added).

${ }^{175}$ See supra pt. IV.A.2. 
process, an adjudicatory outcome might be out of sync with the reality, and thus both offensive and ineffective, and therefore illegitimate.

This is precisely why the Thai Cigarette panel under the old GATT dispute settlement mechanism was criticized so harshly. Despite the World Health Organization (WHO)'s support for the Thai ban on foreign cigarettes to protect public health in developing countries, the GATT panel struck it down on the ground that Thailand failed to prove that its ban was the least trade restrictive. The panel viewed that Thailand could have found other alternatives, which were highly hypothetical and might have only been effective to rich countries. This northern bias can also be found in a more recent case. In Dominican Cigarettes, ${ }^{176}$ the $\mathrm{AB}$ struck down a Dominican tax stamp requirement simply because the Court was not persuaded by the Dominican Republic's regulatory decision and thus held that the Dominican Republic failed to prove the effectiveness of the tax stamp requirement. In doing so, the $\mathrm{AB}$ failed to realize that for a developing country like the Dominican Republic, the AB's own alternatives, such as conventional enforcement measures, would not work in achieving the level of protection which the Dominican Republic desired to pursue with its limited budget and staff.

The Court's lack of regulatory deference to developing countries,, when juxtaposed with a diametrically opposite position in other cases involving developed countries, tends to arouse a suspicion on the Court's legal realism, i.e., its bias against less powerful WTO members. In Hormones, Asbestos and Gambling, which involved politically powerful developed countries, such as the EC and the Unites States, the Court seemed to be quite deferential to local regulators who stuck to a highly conservative regulatory position, such as a zero-tolerance policy. ${ }^{177}$ Yet, in other cases, such as Salmon, Dominican Cigarette and Korean Beef, which involved politically less powerful members, such as Australia, Dominican Republic and Korea, the Court seemed to feel more comfortable in second-guessing local regulators' decisions and presenting its own prescriptions. Therefore, legal realists might contend that the Court instrumentalizes the BOP as a "tool to support result-oriented findings." 178

\section{Finality without Compliance Pull: Legitimacy at Risk}

The WTO is not a World Government nor does it have a well-developed legislative mechanism as seen in other institutions, such as the European Union. Moreover, socio-cultural foundations for risks and regulation vary among different members. This lack of both positivistic infrastructure and common moral foundations among members tends to disenable the WTO tribunal from producing truly legitimate

${ }^{176}$ Appellate Body Report, Dominican Republic-Measures Affecting the Importation and Internal Sale of Cigarettes, ๆ71, WT/DS302/AB/R, (Apr. 23, 2005).

${ }^{177}$ See Isabelle Van Damme, Sixth Annual WTO Conference: An Overview, 9 J. INT'L ECON. L. 749, 755 (2006) (observing that the $\mathrm{AB}$ in Gambling gave higher deference to the responding party through the $\mathrm{BOP})$.

${ }^{178}$ Pauwelyn, Evidence, Proof and Persuasion, supra note_, at 258. 
answers to controversial regulatory disputes involving health risks and regulatory responses. In other words, with little shared regulatory ethos, i.e., shared assumptions on regulatory decision-making, as well as administrative and political efforts to build up such ethos via mutually recognized and trusted institutions, any substantive closure on highly combustible issues, such as regulations over beef hormones or genetically modified foods, by an unelected international tribunal lacks a base for legitimization, and thus appears as imprudent judicial activism. ${ }^{179}$

Even if the Court attempts to close a case by rendering a final, substantive answer to a dispute, the losing party can re-open the case merely by window-dressing violative measures, instead of truly implementing the answer. Then, the winning party will have to re-commence a new litigation in an attempt to re-close the original dispute. The World Trade Court's incapability to close a dispute is not merely attributable to parties' insincere implementation of its original decision. In many cases, especially those involving controversial and complicated public health policies, the Court's final decision might not be final, or at least might not be regarded final by the losing party, for a number of reasons.

First of all, it would be very difficult, if not impossible, for the Court to digest all the sophisticated, technical scientific evidence and evaluate them to produce a final answer. Second, as discussed above, ${ }^{180}$ the Court's interpretation of science in a specific context may diverge from that of members. Under these circumstances, if the Court's ruling is based on its own substantive processing of all the scientific evidence, such a ruling might be hard for the losing party to accept. Third, since more often than not the Court's decision addresses only limited, specific provision-based issues, such decisions could not fully address the root of an underlying dispute over a certain regulatory policy. ${ }^{181}$ Under these circumstances, as Richard Gaskin aptly observed, the Court might broaden the existing divisions between the litigants, rather than settling their dispute. ${ }^{182}$

Therefore, the Court encroaches upon its legitimacy as a neutral adjudicative organ when it renders substantive justice based on its own weighing and balancing over highly controversial and sophisticated issues such as health risks. ${ }^{183}$ Both parties and observers might translate the Court's decision as its own subjective value, or even moral statement on these political subjects, instead of a case-specific ruling on certain narrow

${ }^{179}$ Jürgen Habermas, Between Facts and Norms: An Author's Reflections, 76 DENV. U. L. REV. 937, 940 (1999).

${ }^{180}$ See supra pt. IV.B.3.

181 Panel Report, European Communities-Approval and Marketing of Biotech Products, \$4.5, WT/DS293/R (Sept. 29, 2006).

${ }^{182}$ GASKIN, supra note_, at 208.

${ }^{183}$ Cf. David A. Wirth, European Communities Restrictions on Imports of Beef Treated with Hormones-Non-Tariff Barriers-Control of Food Additives-Scientific Basis for Restrictions - WTO Dispute Settlement Mechanisms-Scope of Review, 92 AM. J. INT'L L. 755, 759 (1998) (raising the issue of legitimacy from a public health perspective over "scientific tests employed in the adversarial, adjudicatory setting of dispute settlement under a trade agreement"). 
legal issues. ${ }^{184}$ It is likely that parties and observers view that the Court itself is right or wrong, rather than noting that a specific decision which it renders may be right or wrong.

Concededly, all disputes may potentially be political cases. Nonetheless, these issues are not traditional trade issues such as tariffs and discrimination in which the Court tends to enjoy a certain aura of legitimacy both from its time-honored jurisprudence on these issues and from the relatively clear-cut nature of the cases. Yet, certain regulatory issues are still in their adolescence both inside and outside the WTO. Countries have yet to develop a common language over widely shared premises in tackling these troublesome issues. Without these common grounds, a losing party will be reluctant to accept any balancing test exercised by the Court sharing with it none of such regulatory ethos. This legitimacy risk tends to become more salient when the losing party is a poor country to which any high regulatory standards might be potential trade barriers impeding and hindering their market access to rich countries.

Finally, cognitive psychology casts dark clouds over final rulings rendered by Herculean judges. Obviously, both panelists and the Appellate Body members are neither Hercules nor any other superhuman. They are just humans, like everyone else, prone to errors and biases, especially "cognitive" ones. When they process and interpret critical scientific evidence presented by parties, they may adopt their own perspectives, or heuristics, which selectively filter certain evidentiary objects, such as scientific reports or expert opinions, and thus influence their probative determinations. ${ }^{185}$ This "cognitive filtering" 186 tends to question the very rationale of the normative possibility of "objective assessment" under Article 11 of the DSU.

This cognitive bias may be further maintained or reinforced by "political" considerations of panelists or the Appellate Body members over their decisions. As long as their appointment, and even selection, remains "political rather" than meritorious, they are keen to political ramifications of their decisions. From a legal realist's perspective, they may choose who should win even before they hear the case solely in accordance with what and who are involved. They may also be tempted to blend adequate nuances and subtleties, often in the form of dicta, with their decisions, paying certain face-making tributes to losers.

\section{Discharging the World Trade Court's Burden: A Procedural Turn}

${ }^{184}$ Cf. Mark D. Rosen, Defrocking the Courts: Resolving 'Cases or Controversies,' Not Announcing Transcendental Truths, 17 HARV. J.L. \& PUB. POL'Y 715, 728 (1994).

${ }^{185}$ See generally Albert J. Moore, Trial by Schema: Cognitive Filters in the Courtroom, 37 UCLA L. REV. 273 (1989).

${ }^{186} \mathrm{Id}$. 


\section{A. A Copernican Turn: Legitimacy over Finality}

The Court, in adjudicating those WTO disputes involving risk regulations and other similar social regulations, has determined who to prove, what to prove and whether to prove from the standpoint of Herculean judges which render definite right (substantive) answers with its transcendental authority. This judicialization of science tends to discount scientific uncertainty as well as unique local regulatory context, thereby making losing parties resist accepting final decisions. That is, adjudication in the WTO is not likely to close risk-related disputes, and parties would continue to claim substantive authority on its own position to dismiss the other party's case. Losing parties would be tempted to window dress the Court's decision and eager to find circumventive measures to stand by its original position. ${ }^{187}$ Ironically, judicialization of science tends to drive parties to cling to the "transcendental critiques" which trivialize the very objective authority of science. ${ }^{188}$

At this juncture, one might be tempted to overcome this substantive dilemma by perfecting the Court's technical criteria, such as streamlining the standards of proof in the line of "preponderance of evidence" and "beyond a reasonable doubt" ${ }^{189}$ or bestowing a higher degree of deference to one party, such as a regulating party. ${ }^{190}$ However, this attempt to articulate the standard of proof seems to make no practical differences as long as the Court's standard of review remains substantive. After all, whether the Court is convinced or not hinges on its free evaluation of evidence and arguments adduced by parties.

If the Court cannot overcome the aforementioned substantive dilemma, it must avoid the dilemma. Instead of closing indefinite cases by prescribing definite answers, the Court should encourage parties to continue talking, deliberating and cooperating with each other until they reach a mutually acceptable regulatory solution. To achieve this, the Court may unearth procedural elements, such as reason-giving, embedded in major provisions, and determine the $\mathrm{BOP}$ questions (who to prove, what to prove and whether to prove) for these provisions in accordance with parties' performance of those procedural disciplines. ${ }^{191}$

${ }^{187}$ EU Approves Farm Animal Hormone Ban, Bridges WeEkly Trade News Digest, Vol.6, No. 43, Dec. 20, 2002.

${ }^{188}$ GASKIN, supra note , at 146.

${ }^{189}$ But see Walker, supra note_, at 290-95 (prescribing certain standards of proof to a WTO panel and the Appellate Body).

${ }^{190}$ Christoforou, supra note , at 644 (arguing that "in the area of food safety and health protection, the burden of proof for parties challenging trade barriers would be higher than for the defending WTO member" because "a wrongful finding could have potentially disastrous effects on the lives of millions of people").

${ }^{191}$ Some commentators view that the Court has already performed this task. See Armin von Bogdandy, Law and Politics in the WTO-Strategies to Cope with a Deficient Relationship, 5 MAX PLANCK Y. B. U. N. L., 609, 667 (2001) (trenchantly observing that the "Appellate Body proceduralizes the substantive WTO obligations and compels the members to try to achieve a multilateral consensus"). 
One might argue that the Court should accord a regulating country an absolute deference in risk determination. As Cass Sunstein, Richard Pildes, and Kip Viscusi observe, any risks can be characterized by their "contextual" circumstances and thus proved to be sui generis. For example, people tend to perceive uncontrollable, artificial, and involuntarily imposed risks more seriously than other controllable, natural, and voluntarily accepted risks, even though the probability that these two different risks may materialize are actually identical. ${ }^{192}$ In this situation, democratic rationality may entail a conservative regulatory posture, even if it proves to be unscientific in a technical sense, and SPS would not find such conservatism as arbitrary or unjustifiable.

However, this position overlooks the dynamic nature of people's perception of risks. People's original perceptions of risks are prone to change by means of further education. Thus, any given perception cannot but be provisional and subject to future alteration. This is why even deference to a regulating country in the line of in dubio mitius should always be accompanied by certain procedural disciplines which not only prevent any abuse of such deference but also keep the door of enlightenment open. The Court can effectively oversee any abuse of deference by scrutinizing the regulating country's adherence to procedural duties explicit and implicit under the SPS Agreement. If the regulating country respects these duties in setting its own level of protection, and yet such measure still restrains trade, this restraint must be tolerated. ${ }^{193}$

\section{B. Discharging the Court's Burden: Reinterpreting WTO Provisions on Risk Regulation}

\section{Necessity Test (GATT Article XX)}

The Court's "weighing and balancing test" may impose a high probative threshold on a defending (regulating) country, requiring it to prove that the measure in question was the least trade restrictive and thus there were no other reasonably available alternatives. Because it is the Court that actually weighs and balances those actual and hypothetical policy options, the outcome of such weighing and balancing may be quite detached from the local reality. This second-guessing of risks becomes unhealthy judicial activism, which goes beyond the Court's mandate as an arbiter, not a legislator. It also self-contradicts another interpretive stance in similar (risk-related) issues represented by in dubio mitius. All these problems tend to eventually undermine the Court's legitimacy.

In fact, this test is a digression from the Court's previous laudable hermeneutics labeled the "chapeau test." In earlier GATT Article XX cases, such as Gasoline and Shrimp-Turtle, the Court took the local regulatory autonomy seriously and deferred the

\footnotetext{
${ }^{192}$ Scott Medlock, NRA=No Rational Argument? How the National Rifle Association Exploits Public Irrationality, 11 TEX. J. C.L. \& C.R. 39, 48 (2005).

${ }^{193}$ Appellate Body Report, United States-Import Prohibition of Certain Shrimp and Shrimp Products, 『15, WT/DS58/AB/R (Oct. 12, 1998).
} 
issue of whether the regulation was a legitimate exercise of its policy objective to a regulating country. ${ }^{194}$ Instead, it focused on the procedural aspects of the regulation, i.e., whether the measure was applied in an arbitrary or unjustifiable manner stipulated in the introductory language of Article XX (chapeau). The Court breathed new life into this quite mundane language, which had been nearly dead letters before, and created a new procedural hermeneutics of regulatory cooperation and due process. Under the chapeau of Article XX regulating countries have to prove that they do take into account the interests of exporting countries which might be negatively affected by the former's regulation, ${ }^{195}$ and that the regulation respected the due process principle in their legal system. ${ }^{196}$

The chapeau test is a mature balance-striker between free trade values and regulatory autonomy (non-trade values) in that it highlights "how" a measure is applied, rather than "what" the measure really is. The Court should further develop this line of jurisprudence, rather than weighing and balancing regulatory details on its own discretion. If a regulating party demonstrates that it seriously engaged with negatively affected countries, such as exporting countries, through consultation and negotiation, the Court should decide that the regulating party has discharged its BOP under GATT Article XX, even if this engagement bore no substantial outcome. ${ }^{197}$ On the other hand, if the evidence showed that the regulating party refused to work with the exporting countries or responded to their inquiries in a dismissive manner, the Court should rule that the regulating party has not met its $\mathrm{BOP}$ under Article XX.

In sum, the restoration of the chapeau test will encourage parties to engage in more regulatory dialogue and cooperation because this is what they should prove under GATT Article XX. Thus, this test envisions a "good and responsible government" which takes into account its trading partners' interests in the era of interdependence and globalization. ${ }^{198}$

\section{Harmonization (SPS Article 3)}

In Hormones, the Court recognized the defending (regulating) parties' right to depart from international standards and thus required complaining parties to prove that

${ }^{194}$ Appellate Body Report, United States-Standards for Reformulated and Conventional Gasoline, 28, WT/DS2/AB/R (Apr. 29, 1996); Appellate Body Report, United States-Import Prohibition of Certain Shrimp, 『14, WT/DS58/AB/R (Oct. 12, 1998).

${ }^{195}$ United States - Standards for Reformulated and Conventional Gasoline, WT/DS2/9, Appellate Body and Panel Report, as amended, adopted on May 20,1996, at 26-27.

196 .United States--Import Prohibition of Certain Shrimp and Shrimp Products, WT/DS58, Appellate Body and Panel Report, as amended, adopted on Nov. 6, 1998, I 181.

${ }^{197}$ Appellate Body Report, United States-Import Prohibition of Certain Shrimp and Shrimp Products, \172, WT/DS58/AB/R (Oct. 12, 1998).

${ }^{198}$ von Bogdandy, supra note_, at 613. 
such departure would lack scientific justification. ${ }^{199}$ However, this interpretation weakened the normative prominence of international standards by constructing the compliance with these standards as a mere option, not as an obligation, despite the explicit language under SPS Article 3.1 which requires members to base their sanitary measures on these standards.

Under the SPS Agreement, the Codex standards explicitly referenced in Annex A are a reincarnation of science. ${ }^{200}$ These standards embody views of an epistemic community in a given sector as well as its professional accountability. ${ }^{201}$ They are a representative repository of scientific evidence, and therefore should not be taken lightly. Both the preamble and Article 3 attest that harmonization via international standards is one of the main objects and purposes of the SPS Agreement. ${ }^{202}$

Therefore, the Court should take international standards more seriously. From this standpoint, Article 3.1 tends to create a procedural obligation to seriously engage in international standards, i.e., a good faith effort to adopt international standards. The Court should guide parties to focus on this procedural aspect in discharging their proof burdens as to Article 3.1-3.3. In particular, the Court should interpret that Articles 3.4 and 5.8 inform Article 3.1-3.3. Article 3.4 requires members to engage in serious regulatory dialogue over international standards, ${ }^{203}$ and Article 5.8 mandates a regulating member departing international standards to respond to an exporting member's inquiries. $^{204}$

Granted, international standards may not satisfy all the members. Yet, a regulating member departing from these standards may at least present its different views in a

\footnotetext{
${ }^{199}$ Appellate Body Report, European Communities-Measures Concerning Meat and Meat Products (Hormones), ๆฯ108-9, WT/DS26/AB/R (Jan. 16, 1998).

${ }^{200}$ But see von Bogdandy, supra note, at 642 (emphasizing that the "world view of the natural sciences are often one-sided and biased by the peculiarities of their own, specialized scientific community").

${ }^{201}$ But see von Bogdandy, supra note,, at 636-38 (observing that the Codex standard for hormones was enacted by a thin majority (33-29) within the Commission, under the U.S.' meat industries' heavy lobbies and against the EC's position based on precaution and moral consideration). Nonetheless, this is also the case in most domestic regulatory statutes.

${ }^{202}$ See Heiskanen, supra note_, at 9-10 (observing that SPS Agreement "expressly subscribes to the philosophy of positive harmonization").

203 "Members shall play a full part, within the limits of their resources, in the relevant international organizations and their subsidiary bodies, in particular the Codex Alimentarius Commission, the International Office of Epizootics, and the international and regional organizations operating within the framework of the International Plant Protection Convention, to promote within these organizations the development and periodic review of standards, guidelines and recommendations with respect to all aspects of sanitary and phytosanitary measures." SPS, supra note,, art. 3.4.

204 "When a Member has reason to believe that a specific sanitary or phytosanitary measure introduced or maintained by another Member is constraining, or has the potential to constrain, its exports and the measure is not based on the relevant international standards, guidelines or recommendations, or such standards, guidelines or recommendations do not exist, an explanation of the reasons for such sanitary or phytosanitary measure may be requested and shall be provided by the Member maintaining the measure." SPS, supra note_, art. 5.8
} 
relevant forum, such as the Codex Alimentarius Commission, to persuade other members to modify these standards, if it truly means to respect the Article 3.4 requirement. Likewise, the regulating member should also fulfill the reason-giving requirement under Article 5.8. The Court should demand parties, whichever bear the BOP, to prove these aspects. If a regulating party forsakes international standards without performing these procedural obligations, it would be sufficient to create a presumption against scientific justification since under these circumstances the measure could be presumed to be a unilateral regulatory determination with no involvement with the scientific community.

\section{Risk Assessment (SPS Article 5.1)}

The Court should interpret that the reason-giving requirement under Article 5.8 also informs Article 5.1. If a respondent fails to engage with a requesting country, this is tantamount to admitting that the requesting country, i.e., the potential complainant, has made a prima facie case since such failure generates a reasonable presumption that the respondent's SPS measure was adopted without reasons which connote scientific justification. ${ }^{205}$

Likewise, the Court may link procedural disciplines under Article 7 (Transparency) as well as Annex B (Transparency of Sanitary and Phytosanitary Regulations) to the risk assessment requirement under Article 5.1. For example, if a complainant has requested to a defendant "the products to be covered by the regulation together with a brief indication of the objective and rationale of the proposed regulation"206 but received no genuine responses, it could generate a presumption against the regulating Member (defendant)'s fulfillment of the risk assessment obligation. In other words, if the defendant has failed to present a proper justification for its SPS measure, one might raise a reasonable suspicion that such measure was adopted without necessary disciplines, such as risk assessment based on scientific evidence. Under these circumstances, an initial BOP borne to the complainant may be shifted to the defendant, which should now prove that it nonetheless performed risk assessment. Procedural flaws, such as the lack of due process or reason-giving, are often suggestive of substantive deficiencies, such as the lack of a substantial relationship between an alleged internal assessment and an adopted SPS measure.

Suppose the regulating state (defendant) does respond to the inquiring state (complainant) with certain reasons and justification. If the inquiring state is satisfied with

205 "The United States could have requested Japan, pursuant to Article 5.8 of SPS Agreement, to provide "an explanation of the reasons" for its varietal testing requirement, in particular, as it applies to apricots, pears, plums and quince. Japan would, in that case, be obliged to provide such explanation. The failure of Japan to bring forward scientific studies or reports in support of its varietal testing requirement as it applies to apricots, pears, plums and quince, would have been a strong indication that there are no such studies or reports." Appellate Body Report, Japan-Measures Affecting Agricultural Products, ๆ137, WT/DS76/AB/R (Feb. 22, 1999).

${ }^{206}$ SPS, supra note_, annex B, §5 (b). 
such reason-giving, no further inquiry will follow, hence no dispute. If the inquiring state, still unsatisfied, raises further questions on scientific justification of the measure, the regulating state should also respond to these additional inquiries in good faith. This series of a question and answer process is likely to constitute a meaningful regulatory dialogue between the regulating and inquiring state. This regulatory dialogue tends to contribute to mitigating, if not eradicating, tensions which stem largely from ignorance and misinformation. This dialectical exchange of reason-demanding and reason-giving by parties concerned is a prerequisite for any regulatory cooperation since such dialogue creates certain room for each party to take into account the other's interests and concerns. Even if such dialogue cannot entail regulatory cooperation and litigation finally ensues, the Court may use parties' arguments and submissions as undisputed facts or at least circumstantial evidence which may assist the Court to discharge its own burden on the BOP. ${ }^{207}$

\section{Risk Management (SPS Article 5.5)}

In determining the appropriate level of protection under Article 5.5 of the SPS Agreement, a regulating party must satisfy many requirements, such as minimizing any restrictive impact to trade and avoiding any arbitrary and unjustifiable distinction. ${ }^{208}$ In fact, these requirements can be translated into certain procedural duties. To minimize trade restriction under Article 5.4, a regulating party should reach out to its trading partners which may be affected by its regulation, such as exporting countries. In other words, this obligation tends to impose on the regulating state a certain procedural duty to cooperate with these exporting countries in consulting and negotiating over possible arrangements which can achieve both goals of regulatory protection and free trade.

Likewise, to avoid any arbitrary and unjustifiable distinction in determining the appropriate level of protection under Article 5.5, the regulating country should investigate and re-investigate whether its SPS measure has been consistent with its hitherto regulatory practice in similar issues and whether it may generate other due process concerns. Naturally, the Court's final decision on whether a regulating country has violated those SPS provisions may depend on whether the country has discharged its burden of proving that it has genuinely adhered to those procedural disciplines.

According to this approach, the AB in Hormones should have interpreted that the EC should prove that it had adequately communicated with other affected parties, e.g., the United States, before it reached the conclusion that artificially-injected hormones were riskier than naturally-occurring hormones. It should not have unconditionally declared that such distinction is "fundamental" and any comparison between these two

207 The Court, as in Hormones, may use them as warning signals or additional factors which help the Court discharge its hermeneutical burdens.

${ }^{208}$ SPS, supra note_, art. 5.5. 
regulatory situations is preposterous. ${ }^{209}$ Admittedly, the AB would still have found the EC's total ban on hormoned beef to be legal under the SPS Agreement, yet for a different reason from the original one, i.e., a procedural, not substantive, reason.

\section{Conclusion}

The current way of discharging the Court's burden of determining the BOP issues, such as who to prove, what to prove and whether to prove, risks illegitimating the Court by rendering transcendental answers in combustible risk-related disputes to parties which have already been entrenched with their own transcendental answers. As a solution, the Court should focus on procedural aspects of WTO obligations in this area so that it can encourage parties to seriously commit themselves to regulatory dialogue and cooperation.

This rethinking of the Court's role is not radical one if one acknowledges that the Court's institutional responsibility is closer to a constitutional court than to a mundane civil court. The purpose of the Court lies not only in simply resolving disputes by picking the winner but also in constituting a legal (regulatory) community within the WTO system. While the Court's hitherto incoherency in the BOP jurisprudence has exacerbated an adversarial struggle of parties and led to ever-lengthening reports, it has certainly failed to nurture a regularized pattern of regulatory discourse among parties concerned. After all, a real closure on any sensitive regulatory dispute with socio-cultural characteristics originates from parties themselves, not from the Court.

The proceduralized hermeneutics proposed here tends to provide both parties with adequate incentives to facilitate regulatory dialogue and regulatory cooperation. An exporting country would like to proactively inquire of an importing country's SPS measure with challenging scientific information which would help the former establish its prima facie case on risk assessment. Even if the importing country had eventually rejected the information, it would still have to register, for the record, other information counteracting the exporting country's original information. This would in turn trigger yet another round of inquiries or regulatory dialogue. As their dialogue deepens, so becomes their level of mutual understanding. The exporting country might be persuaded by the importing country's reason-giving and forsake the idea of a WTO litigation. Or, both parties might have reached a certain regulatory arrangement to resolve their disputes. In sum, this culture of proceduralism will eventually prevent disputes, rather than settle them.

Notably, this strategy of legitimacy over closure seems prudent especially when a fact-finding mission of the Court is severely challenged by scientific uncertainty and disagreement on risks involved. As Lawrence Solum contends, BOP under these

209 Appellate Body Report, European Communities-Measures Concerning Meat and Meat Products (Hormones), ๆ221, WT/DS26/AB/R (Jan. 16, 1998). 
circumstances should be allocated to achieve certain purposes, such as fairness. ${ }^{210}$ The Court's hermeneutical refocusing on procedural disciplines not only enhances the legitimacy of its decision but also helps parties reach mutually acceptable regulatory settlement through continuing regulatory cooperation, which those procedural disciplines tend to provide. This procedural approach will also shelter the WTO from potential criticisms from interest groups, such as environmentalists and consumer advocates, since the Court could refrain from rendering any substantive answers. ${ }^{211}$

In conclusion, the Court's new hermeneutics proposed here ${ }^{212}$ will help parties change their way of engaging with each other in the global trading community.

${ }^{210}$ Lawrence B. Solum, You Prove It! Why Should I?, 17 HARV. J. L. \& PUB. POL'Y 691, 699 (1994).

${ }^{211}$ See Steve Charnovitz, The Supervision of Health and Biosafety Regulation by

World Trade Rules, 13. TUL. ENVTL. L.J. 271, 301 (2000) (predicting that "in adjudicating SPS complaints, the WTO may gain a reputation as a naysayer to health and biosafety regulation").

${ }^{212}$ Horn \& Weiler, supra note_, at 255 (trenchantly observing that "legal hermeneutics is a discourse which is far richer than the thin gruel served up by the $A B$ "). 